\title{
Observing a vulnerable carbon cycle
}

\author{
M.R. Raupach and J.G. Canadell
}

CSIRO Marine and Atmospheric Research, Canberra, ACT 2601, Australia

Global Carbon Project (Earth System Science Partnership: IGBP-WCRP-IHDP-Diversitas)

\begin{abstract}
This chapter sketches an analysis of the implications of carbon-climate vulnerability for carbon observation. Carbon-climate vulnerability is defined as a positive or disturbanceamplifying feedback between an aspect of the carbon cycle (a pool or flux) and physical climate, including atmosphere, oceans and the hydrological cycle. Focussing on processes influencing the atmospheric concentrations of $\mathrm{CO}_{2}$ and $\mathrm{CH}_{4}$, we survey the vulnerabilities of the terrestrial part of the global carbon cycle to perturbation under climate change. Important processes include respiration, fire, land use changes, peatlands, permafrost, and the effects of nutrient limitations. Together, these processes create a significant potential climate change impact (expressed as an estimated positive feedback between changes in temperature and atmospheric $\mathrm{CO}_{2}$ and $\mathrm{CH}_{4}$ concentrations) which is not negligible in comparison with projected direct consequences of anthropogenic emissions. An important requirement for a global carbon observation system is to track and quantify these vulnerabilities.
\end{abstract}

To appear in: Observing the Continental Scale Greenhouse Gas Balance of Europe (eds. H. Dolman, R. Valentini, A. Freibauer). (Springer). 


\section{Introduction}

The carbon cycle and indeed the entire earth system are now inextricably linked with human activities (Global Carbon Project 2003; Steffen et al. 2004; Field and Raupach 2004), so that the "carbon-climate-human system" constitutes a single, coupled entity in which interacting processes link all of its major components. Linking processes of primary significance include:

(1) the human drivers of energy consumption and land use change, through increases in both population and per capita consumption;

(2) the role of human energy systems as sources of $\mathrm{CO}_{2}$ and other greenhouse gases (GHGs);

(3) land use change (deforestation, increases in agricultural and urban land use) and its consequences for both GHG emissions and also resource (water, land, ecosystem) condition;

(4) climate forcing by $\mathrm{CO}_{2}$ and other GHGs, following from drivers (1), (2) and (3);

(5) the changing roles of the ocean and the terrestrial biosphere as sinks and sources of $\mathrm{CO}_{2}$ and other GHGs, driven by the disequilibrium of the earth system through human activities;

(6) impacts of climate change through declines in resource condition and human wellbeing;

(7) attempts by human societies to reduce their impact on the global environment, for example through reductions in GHG emissions to avoid "dangerous climate change" (Schellnhuber et al. 2006.

Through the first six of these processes humankind is unintentionally influencing the earth system, while the seventh is an effort to manage global-scale human impacts on the earth system by mitigating their causes.

An integrated global carbon observation system (Ciais et al. 2004) is a contribution to 
monitoring the first six of the above processes, and bringing about the seventh. These underlying motivations lead to two broad goals for global carbon observations, respectively oriented towards understanding and management. The former goal is to provide increased understanding of the cycles of carbon and related entities (water, energy, nutrients) in the earth system, contributing to our ability to diagnose trends and to predict future evolution of the carbon-climate system over time scales of decades to centuries. The latter is to provide the global-scale observations of carbon fluxes and greenhouse gas emissions needed to manage the carbon cycle, through emissions reduction programs based on incentive, regulatory or trading mechanisms. Between them, these two goals largely determine the necessary broad attributes of a global carbon observing system. A recent analysis (Raupach et al. 2005) identified seven main attributes for terrestrial carbon observation, which (with slight extension) provide a broad specification of attributes for a complete global carbon observing system. These seven are (1) scientific rigour, (2) global scope and consistency, (3) spatial resolution sufficient to resolve and monitor all important processes, especially carbon fluxes associated with human land use and energy systems; (4) temporal resolution sufficient to monitor variability in fluxes from weather to climate time scales; (5) integrated monitoring of all relevant entities $\left(\mathrm{CO}_{2}, \mathrm{CH}_{4}, \mathrm{CO}\right.$, VOCs, black carbon, together with fluxes of water, nutrients and other entities relevant in modulating carbon fluxes); (6) process discrimination (for instance between anthropogenic and nonanthropogenic fluxes, and between contributions to net fluxes such as assimilation, autotrophic and heterotrophic respiration); and (7) quantification of uncertainty.

Here we discuss the implications of carbon-climate vulnerabilities for the attributes of an integrated carbon observation system. By "carbon-climate vulnerability" we mean a positive, 
disturbance-amplifying feedback between an aspect of the carbon cycle (a pool or flux) and physical climate, including atmosphere, oceans and the hydrological cycle. In particular, carbonclimate vulnerabilities are processes causing global warming through the enhanced greenhouse effect to be larger than it otherwise would be in their absence.

Two ways have been used recently to quantify carbon-climate vulnerability in the above sense. The first is a risk-assessment methodology (Gruber et al. 2004, henceforth G2004) involving heuristic, judgement-based estimates of the releases of carbon to the atmosphere from several terrestrial and oceanic pools under projected changes (to 2100) in temperature, ocean circulation and other physical climate properties. G2004 expressed the results of the assessment as ellipses on a plane with axes defined by the mass of carbon released and a qualitatively judged probability of release (with small releases having high probability and vice versa). This approach is a valuable beginning, but cannot properly quantify carbon-climate feedbacks by estimating the extent to which a carbon release is modified by the extra climate change induced by the release itself.

The second, much more quantitative approach is through the use of fully coupled carbonclimate models. Eleven such models were compared in the recent Coupled Climate-Carbon Cycle Model Intercomparison Project ( $\left.\mathrm{C}^{4} \mathrm{MIP}\right)$ (Friedlingstein et al. 2006). The models included full physical climate, ocean carbon biogeochemistry responsive to temperature and atmospheric $\mathrm{CO}_{2}$, and terrestrial carbon dynamics responsive to light, water, temperature and $\mathrm{CO}_{2}$. All models were run from 1850 to 2100 under a prescribed emissions scenario (the IPCC SRES ${ }^{1}$ A2

${ }^{1}$ (IPCC) Intergovernmental Panel on Climate Change; (SRES) Special Report on Emissions Scenarios 
scenario; see later for details). The results showed that coupling of the carbon cycle to climate through temperature-dependent processes led to increased atmospheric $\mathrm{CO}_{2}$ in 2100 of 20 to 200 ppm (augmenting a $\mathrm{CO}_{2}$ concentration of around $700 \mathrm{ppm}$, depending on the model) and an increase in predicted global temperature of 0.2 to $2 \operatorname{degC}$ (augmenting an enhanced-greenhouseinduced warming of around $4 \mathrm{degC}$, likewise depending on the model). There were substantial differences among the 10 models, stemming both from carbon cycle parameterisations (for instance the temperature response of terrestrial heterotrophic respiration) and also the behaviour of modelled physical climate (for instance the tendency of some of the models to dry out the Amazon as the model climate warms). As a means of studying carbon-climate vulnerabilities, fully coupled carbon-climate models are comprehensive, but they are laborious and difficult to parameterise because of model complexity. The extensive $\mathrm{C}^{4} \mathrm{MIP}$ runs to date have focussed on only a few of the potentially important feedback processes.

In this chapter we analyse carbon-climate vulnerability and its implications for carbon cycle observations. The plan of the chapter (following this brief introductory section) is that Section 2 surveys the major feedbacks in the carbon-climate-human system at a general level, including forcing by and feedbacks on human actions. Section 3 focuses on carbon-climate feedbacks involving terrestrial processes, drawing from $\mathrm{C}^{4} \mathrm{MIP}$ results and other sources. Attention is given to both $\mathrm{CO}_{2}$ and $\mathrm{CH}_{4}$. Section 4 proposes a perturbation-based approach using simple models for analysing carbon-climate vulnerabilities, and illustrates the approach with a semi-quantitative evaluation of the response of permafrost carbon pools to global change. Finally, Section 5 discusses the implications of carbon vulnerability for integrated carbon observation. 


\section{Feedbacks and Vulnerabilities in the Carbon-Climate-Human System}

The trajectories of climate and the carbon cycle are coupled by atmospheric composition. Of the linking groups of processes mentioned in the introduction, four are of central importance for feedbacks and vulnerabilities in the contemporary carbon-climate-human system. The first is enhanced radiative forcing by greenhouse gases, $\mathrm{CO}_{2}$ and $\mathrm{CH}_{4}$ being the largest contributors. The other three correspond to the three major groups of fluxes in the atmospheric $\mathrm{CO}_{2}$ and $\mathrm{CH}_{4}$ budgets: emissions from human activities, ocean-atmosphere exchanges, and land-atmosphere exchanges. The next section focuses on land-atmosphere exchanges in more detail, but before doing so we examine all four groups of processes in general terms.

Radiative forcing: The carbon cycle accounts for some, but not all, of the processes involved in the radiative forcing of climate. Total radiative forcing can be considered as the sum of three contributions: (1) from $\mathrm{CO}_{2}$, (2) from non- $\mathrm{CO}_{2} \mathrm{GHGs}$ (mainly $\mathrm{CH}_{4}$, halocarbons, $\mathrm{N}_{2} \mathrm{O}$, ozone), and (3) from non-gaseous mechanisms (mainly aerosols, albedo changes, solar variations). The first two are relatively well known (IPCC 2007): the current (2001-2005) radiative forcing from $\mathrm{CO}_{2}$ is $+1.66 \pm 0.17 \mathrm{~W} \mathrm{~m}^{-2}$; and the forcing from non- $\mathrm{CO}_{2} \mathrm{GHGs}$ is about $+1.3 \mathrm{~W} \mathrm{~m}^{-2}(+0.48$ from $\mathrm{CH}_{4},+0.34$ from halocarbons, +0.16 from $\mathrm{N}_{2} \mathrm{O}$, and +0.30 from ozone). The third contribution, from aerosols, albedo changes and solar variations, is highly uncertain but is considered to be negative, current estimates being around $-1.3 \pm 1 \mathrm{~W} \mathrm{~m}^{-2}$ (IPCC 2007). The current net radiative forcing $\left(+1.6 \mathrm{~W} \mathrm{~m}^{-2}\right.$, range +0.6 to +2.4 ) drives global warming (at about $0.016 \mathrm{degC} \mathrm{y}^{-1}$ over the period 1980 to 2005). Thus, current net radiative forcing is approximately equal to the radiative forcing from $\mathrm{CO}_{2}$ alone, with other contributions approximately cancelling. This does not imply that future forcing will behave this way, because 
all three contributions to radiative forcing are dependent on emissions scenarios and also on future climate through climate feedbacks, so the three contributions will evolve differently under these influences. In summary, a carbon budget and a radiative forcing budget are different entities, but they share a large common term associated with rising atmospheric $\mathrm{CO}_{2}$.

Emissions from human activities: The global balance of atmospheric $\mathrm{CO}_{2}$, shown in Figure 1, demonstrates that human activities are the overwhelmingly dominant contribution to the current disequilibrium of the global carbon cycle. Fossil fuel emissions were about $7.2 \pm 0.3 \mathrm{PgC}^{-1}$ for the period 2000-2005, and increased at over $3 \% \mathrm{y}^{-1}$ for $2000-2005$ compared with $1 \% \mathrm{y}^{-1}$ for 1990-1999 (Canadell et al. 2007a; Raupach et al. 2007). Emissions from land clearing have changed more slowly, averaging about $1.5 \pm 0.5 \mathrm{PgC}^{-1}$ (Canadell et al. 2007a).

The atmospheric $\mathrm{CH}_{4}$ balance involves 10 major source terms and three sink terms, and is discussed in more detail later. Of the current total source, about $2 / 3$ is anthropogenic.

The four main groups of IPCC SRES scenarios (Nakicenovic et al. 2000) all involve major increases in $\mathrm{CO}_{2}$ emissions over the period to 2100 (Table 1), ranging from 12 to $17 \mathrm{PgC}^{-1}$ in 2050 and from 7 to $30 \mathrm{PgC}^{-1}$ in 2100 . Methane emissions are also projected to increase in most scenarios. From the present standpoint of vulnerability analysis, the important question is: are these emissions scenarios significantly dependent on climate itself, so that different emissions scenarios would result from different climate change scenarios? While climate is just one among the many economic, social and environmental factors influencing the scenarios, there are potential mechanisms for feedbacks on emissions scenarios from climate change. Examples include increased energy use to buffer against adverse effects of climate 
change (eg: air conditioning); increased energy use to augment resources threatened by climate change (eg: desalination to supplement water supplies); and increased military energy use brought on by climate-induced geopolitical instability.

Ocean-atmosphere exchanges: The ocean is a major $\mathrm{CO}_{2}$ sink, currently absorbing about $25 \%$ of fossil-fuel emissions (Figure 1). This will continue over the next century according to $\mathrm{C}^{4} \mathrm{MIP}$ carbon-climate models (Friedlingstein et al. 2006). There are several time scales for oceanatmosphere exchanges related to different ocean carbon pools, but even the shortest is long enough for ocean uptake of $\mathrm{CO}_{2}$ to be fairly smooth from year to year (Figure 1). Several reviews (Jacobson et al. 2000; Steffen et al. 2004; Le Quere and Metzl 2004; Greenblatt and Sarmiento 2004) describe the processes involved, which include (1) air-sea exchange of $\mathrm{CO}_{2}$, driven by the difference in $\mathrm{CO}_{2}$ partial pressure $\left(\mathrm{pCO}_{2}\right)$ between atmosphere and ocean surface waters; (2) buffering between dissolved $\mathrm{CO}_{2}$ and DIC (total inorganic carbon including $\mathrm{CO}_{2}$, $\mathrm{H}_{2} \mathrm{CO}_{3}, \mathrm{HCO}_{3}{ }^{-}$and $\mathrm{CO}_{3}{ }^{2-}$ ), which means that only about $10 \%$ of the carbon crossing the air-sea interface contributes to aqueous $\mathrm{pCO}_{2}$, with the rest appearing as other forms of DIC; (3) the ocean circulation pump, by which ocean circulations export carbon from surface to deep ocean waters; and (4) biological pumps, by which soft-tissue and carbonate detritus from ocean biota in the surface layer export carbon to deep waters as they sink.

All of these processes are subject to climate feedbacks. G2004, in their risk-assessmentbased analysis of carbon cycle vulnerabilities, identified six feedbacks. First, chemistry leads to a positive feedback because ocean $\mathrm{pH}$ falls as $\mathrm{CO}_{2}$ is taken up, thereby altering the $\mathrm{CO}_{2} / \mathrm{DIC}$ partition and reducing uptake. Second, temperature increases lead to a similar positive feedback through the $\mathrm{CO}_{2} / \mathrm{DIC}$ partition. Third, changes in deep ocean circulation (mainly through 
increasing vertical stratification) increase ocean equilibration times, inducing a positive feedback through reduced uptake over time scales of 10 to 100 years since the mixing time scale becomes longer. Fourth, ocean circulation changes alter the equilibrium carbon distribution itself (in addition to changing the equilibration time scale), which when coupled with the biological pump leads to a negative feedback because upward transport of DIC from deep to surface waters is reduced but the downward biological pump is not. Fifth, the biological pump is subject to large influence by climate change, but uncertainties are so high that it is not yet possible to identify whether these influences add up to a an overall positive or a negative feedback. Sixth, there is the possibility of release from the vast stores of methane hydrates in sediments under continental shelves (and in permafrost). Such a release would constitute a massive positive (heating) feedback on the climate system, but is rated by G2004 as a high-risk, low-probability scenario.

Land-atmosphere exchanges: Like the oceans, the terrestrial biosphere currently takes up about $25 \%$ of fossil fuel emissions of $\mathrm{CO}_{2}$, but unlike the ocean sink, the terrestrial $\mathrm{CO}_{2}$ sink varies enormously from year to year (Figure 1). Similarly, on longer (100 year) time scales, $C^{4}$ MIP results suggest higher variability for the terrestrial than the ocean $\mathrm{CO}_{2}$ sink, both in time and between individual models in $\mathrm{C}^{4} \mathrm{MIP}$. Land-atmosphere exchanges are also critical in the $\mathrm{CH}_{4}$ budget. These issues are explored in more detail in the next section.

\section{Vulnerabilities in Terrestrial Carbon Pools and Fluxes}

The terrestrial carbon balance equates the net change in terrestrial biospheric carbon to the sum of carbon fluxes into the terrestrial carbon pool. These fluxes include land-air gaseous exchanges, waterborne and airborne particulate transport, and product removal by humans. The 
focus here is on the first, which is the most significant for the global carbon budget (though the others can be important particularly for regional carbon budgets). Gaseous carbon exchange between terrestrial systems and the atmosphere occurs through fluxes of $\mathrm{CO}_{2}$ and several other species including $\mathrm{CH}_{4}$, Volatile Organic Compounds (VOCs) and CO. The $\mathrm{CO}_{2}$ exchange dominates the mass flux, but exchanges of other species have significant effects on radiative forcing. Here we summarise the main processes leading to vulnerabilities in land-air exchanges of carbon as $\mathrm{CO}_{2}$ and $\mathrm{CH}_{4}$, since these two entities are the most important from both mass-flux and radiative-forcing standpoints.

\subsection{Vulnerabilities Associated with $\mathrm{CO}_{2}$ Exchanges}

Table 2 summarises the main processes affecting the net land-atmosphere flux of $\mathrm{CO}_{2}$ in terrestrial systems. The table identifies three classes of driver for changes in these processes: $(a)$ changes in atmospheric composition $\left(\mathrm{CO}_{2}\right.$ fertilisation, nutrient effects, pollution effects); $(b)$ changes in physical climate (temperature, precipitation, light); and (c) changes in land use and land management. Table 2 also identifies whether the process is a source or a sink, an attribute that has no simple correlation with the class of driver. All processes driven by changes in atmospheric composition (a) and physical climate (b) are directly involved in carbon-climate feedbacks. An additional dimension to terrestrial carbon vulnerability arises through processes driven by changes in land use and land management $(c)$, which provide direct couplings between the terrestrial carbon cycle and human actions in the carbon-climate-human system.

Most of the processes listed in Table 1 are vulnerable to major changes over the next century, and many have already changed significantly over the last century. The most important 
feedbacks and vulnerabilities associated with these processes can be summarised as follows, drawing from a recent review (Canadell et al. 2007b; henceforth C2007). (Note that not all processes listed in Table 2 are discussed in the following).

$\mathrm{CO}_{2}$ fertilisation and its limitation by water and nutrient constraints (a1, a2): It is expected on physiological grounds that plants respond to rising atmospheric $\mathrm{CO}_{2}$ with increased assimilation, leading to increased biomass. The response saturates at around $1000 \mathrm{ppm}$ according to models and laboratory experiments (Farquhar, Caemmerer von and Berry 1980; Farquhar and Sharkey 1982). This $\mathrm{CO}_{2}$ fertilisation process is now incorporated in most terrestrial-biosphere and dynamic-vegetation models (Cramer et al. 2001). However, field results from Free Air $\mathrm{CO}_{2}$ Enrichment (FACE) and other elevated- $\mathrm{CO}_{2}$ studies have been variable (Oren et al. 2001; Nowak, Ellsworth and Smith 2004; Norby et al. 2005). Some actively growing vegetation types (such as temperate, well-watered young forests) show responses in Net Primary Production (NPP) of up to $25 \%$ (Norby et al. 2005), while other, more stressed vegetation types show much lower responses (Nowak, Ellsworth and Smith 2004). Field observations also indicate a saturation of response to $\mathrm{CO}_{2}$ fertilisation at 500 to $600 \mathrm{ppm}$, much lower than expected on physiological grounds. These results indicate that the full possible physiological response to $\mathrm{CO}_{2}$ fertilisation is not manifested in most field environments because of constraints from factors other than $\mathrm{CO}_{2}$, especially nitrogen limitations (Luo et al. 2004). There is also an interaction between water limitation and $\mathrm{CO}_{2}$ fertilisation through the beneficial (to terrestrial carbon storage) effect of increasing $\mathrm{CO}_{2}$ on water use efficiency because of decreased stomatal conductance. This is most pronounced in dry ecosystems (Field et al. 1996; Owensby et al. 1997; Pataki et al. 2000). 
Fertilisation by nitrogen deposition (a3): Early studies (Townsend et al. 1996; Holland et al. 1997) suggested significant enhancement of the terrestrial $\mathrm{CO}_{2}$ sink by $\mathrm{N}$ deposition, especially in mid-latitude northern hemisphere forests where $\mathrm{N}$ limitation is common and deposition rates are high. Later work (Nadelhoffer et al. 1999) has suggested a lower contribution of about $0.25 \mathrm{PgC}^{-1}$ to the current net terrestrial sink of 2 to $3 \mathrm{PgC}^{-1}$. C2007 concluded that it is unlikely that $\mathrm{N}$ deposition will create major new carbon sinks over the next century.

Response of respiration to warming and moisture (b1): Warming increases heterotrophic respiration of soil carbon $(R)$, thus decreasing Net Ecosystem Exchange $(\mathrm{NEE}=\mathrm{NPP}-R)$. Soil moisture is comparably important. Most models incorporate a strong temperature response of soil respiration, quantified by $Q_{10}=R\left(T+10^{\circ} \mathrm{K}\right) / R(T)$, which is a dominant contributor to the source side of the terrestrial carbon balance and is a major reason for predictions that the current terrestrial sink will saturate or reverse in the future. Most of the eleven $\mathrm{C}^{4} \mathrm{MIP}$ models used $Q_{10}=2$ (Friedlingstein et al. 2006). However, as usual, experimental evidence is less clear-cut than modelling assumptions. The review of $\mathrm{C} 2007$ is summarised here in three stages: first, many laboratory and some field studies support high $Q_{10}$ values of 2 or more for soil respiration, and show that $Q_{10}$ decreases with increasing temperature (Lloyd and Taylor 1994). Second, other field studies (Giardina and Ryan 2000; Valentini et al. 2000; Jarvis and Linder 2000; Luo et al. 2001) have suggested that $Q_{10}$ declines after some time as labile soil carbon is respired, leaving more recalcitrant soil carbon for which turnover is slower and less sensitive to temperature. Third, recent studies (Knorr et al. 2005; Fang et al. 2005) have resolved the apparent paradox by analysing the data in terms of separate fast and slow carbon pools (in contrast with earlier studies which analysed all soil carbon in one pool). These newer studies find different temperature 
dependences in $R$ for fast and slow soil carbon pools, with faster pools having more temperature sensitivity.

Response of NPP to warming and moisture (b2): Global terrestrial NPP has increased by 6\% (3.4 $\mathrm{PgC} \mathrm{y}^{-1}$ ) over the two decades from 1981 to 2000, largely because of extension of the growing season in high-northern-latitude ecosystems because of global warming (Nemani et al. 2003). This is associated with an increase in the terrestrial $\mathrm{CO}_{2}$ sink (excluding land use change) from around $0.3 \mathrm{PgC}^{-1}$ in the 1980s to 2 to $3 \mathrm{PgC} \mathrm{y}^{-1}$ in the 1990s (IPCC 2001; Sabine et al. 2004). Most (though not all) $\mathrm{C}^{4} \mathrm{MIP}$ simulations predict a further increase in the terrestrial $\mathrm{CO}_{2}$ sink through the 21 st century, driven largely by $\mathrm{CO}_{2}$ fertilisation (Friedlingstein et al. 2006). This would provide a negative feedback on further climate change. However, new observations of a reduced $\mathrm{CO}_{2}$ sink due to increased climate variability are challenging the hypothesis of an increasing terrestrial $\mathrm{CO}_{2}$ sink in the 21st century. An analysis of Northern Hemisphere terrestrial carbon fluxes (Angert et al. 2005) shows that since 1994, accelerated carbon uptake in early spring was cancelled by decreased uptake during summer, most likely due to hotter and drier summers in middle and high latitudes. The heatwave in 2003 alone reduced the gross primary productivity of European ecosystems by $30 \%$, resulting in a net atmospheric $\mathrm{CO}_{2}$ source of $0.5 \mathrm{PgC}^{-1}$ or 4 years of carbon accumulation in these systems (Ciais et al. 2005).

Permafrost thawing (b5): The carbon store in frozen soils in the Northern Hemisphere has been estimated as over $400 \mathrm{PgC}$, of which around $54 \%$ is in Eurasia, largely in Russia, and $46 \%$ in North America, largely in Canada (Tarnocai 1999). A recent estimate is substantially higher at around $900 \mathrm{PgC}$ (Zimov, Schuur and Chapin 2006). Widespread observations already exist of permafrost thawing leading to the development of thermokarst and lake expansion, followed by 
lake drainage as permafrost further degrades (Camill 2005; Smith et al. 2005;Jorgenson, Shur and Pullman 2006). Preliminary estimates suggest that permafrost area could shrink by up to $25 \%$ with a mean global warming of $2 \operatorname{degC}$ (Anisimov, Nelson and Pavlov 1999). Melting permafrost will increase both $\mathrm{CO}_{2}$ and $\mathrm{CH}_{4}$ emissions from frozen soils. It is estimated for the Canadian permafrost alone that up to $48 \mathrm{PgC}$ could be vulnerable to release under a $4 \operatorname{degC}$ warming scenario (Tarnocai 1999). G2004 suggested that up to $5 \mathrm{PgC}$ could be released from melting permafrost over the next 20 years and up to $100 \mathrm{PgC}$ in the next 100 years, assuming a warming of $2 \operatorname{degC}$ by 2100 and that this warming releases $25 \%$ of the carbon locked in frozen soils (following projected area reductions).

Fire (b6, $\boldsymbol{c 1}$ ): The annual carbon flux to the atmosphere from savanna and forest fires (excluding biomass burning for fuel and land clearing) is estimated to be in the range of 1.7 to $4.1 \mathrm{PgC}^{-1}$ (Mack et al. 1996), mostly as $\mathrm{CO}_{2}$. A recent estimate (van der Werf et al. 2006) gives a fire emission of $2.5 \mathrm{PgC}^{-1} 1997$ to 2004 . In high-intensity fire years such as during El NiñoSouthern Oscillation (ENSO) events, emission from fires can be responsible for as much as $66 \%$ of the atmospheric $\mathrm{CO}_{2}$ growth anomaly (van der Werf et al. 2003). In the long term or over large spatial regions, terrestrial carbon losses from fires may be compensated by the gains during vegetation regrowth. However, a terrestrial carbon imbalance is created during the transition from one disturbance regime to another: this leads to a $\mathrm{CO}_{2}$ sink (or source) when the disturbance frequency is reduced (or increased). Furthermore, trends in fire disturbance frequency are not spatially uniform. For instance, fire exclusion during the twentieth century in many countries has resulted in an increase of biomass in forests and woodlands (Luger and Moll 1993;Houghton, Hackler and Lawrence 2000; Mouillot and Field 2005), and the potential exists for further 
accumulation especially in temperate and subtropical regions. By contrast, increases in annual burned area over the last two decades in boreal North America and some parts of Europe are shifting a long term trend of terrestrial carbon accumulation into one of release to the atmosphere (Kurz and Apps 1999).

Managed and unmanaged forest growth (c2, c3, c4): Directly and indirectly human-induced forest regrowth (through cropland abandonment, vegetation thickening, afforestation and reforestation) accounts for a major contribution to the terrestrial carbon sink of 2 to $3 \mathrm{PgC}^{-1}$ through the 1990s. Several processes are involved, all related to land use and land management. First, forest regrowth on abandoned agricultural land has been identified as one of the most significant mechanisms to explain the net $\mathrm{CO}_{2}$ sink in the Northern Hemisphere, both in the USA (Houghton and Hackler 2000) and in Europe (Janssens et al. 2005). Crop abandonment results in the expansion of relatively young forests with fast growth rates, and therefore with high $\mathrm{CO}_{2}$ sink capacity. Second, woody thickening and encroachment in semi-arid regions and savannas, largely due to fire suppression policies and pasture management, accounts for 22 to $40 \%$ of the US terrestrial carbon sink (Pacala et al. 2001) and is a significant component of the sink in Australia (Gifford and Howden 2001; Burrows et al. 2002). However, these estimates have very large uncertainties. Third, managed afforestation and reforestation has a significant potential as a terrestrial $\mathrm{CO}_{2}$ sink over the 21 st century, though currently only China has seen a substantial increased terrestrial carbon storage $(0.45 \mathrm{PgC})$ by this mechanism, through large reforestation efforts over recent decades (Fang et al. 2001).

Deforestation and land clearing (c5): Deforestation and land clearing, mainly to establish croplands, has released a total of 182 to $199 \mathrm{PgC}$ to the atmosphere over the period from 1800 to 
2000 (DeFries et al. 1999) and is responsible for $33 \%$ of the increase in atmospheric $\mathrm{CO}_{2}$ concentration observed over that period (Houghton 1998). Estimates of emissions from deforestation for the decades of the 1980s and 90s range from 0.8 to $2.2 \mathrm{PgC}^{-1}$ (DeFries et al. 2002; Houghton 2003; Achard et al. 2004) and are expected to continue being significant over the next decades to century.

Peatland and wetland drainage (c6): Peatlands and wetlands in high, temperate and tropical latitudes contain a carbon store of over $450 \mathrm{PgC}$, as soil organic matter. This carbon is largely isolated from decomposition by waterlogged environments and/or low temperatures, but is vulnerable to release to the atmosphere when water tables fall (through land use change or precipitation change) or temperatures rise. When such carbon releases occur, a complex balance exists between $\mathrm{CO}_{2}$ emissions (in oxidising conditions associated with falling water tables) and $\mathrm{CH}_{4}$ emissions (in anoxic conditions associated with high water tables). A Siberian wetland illustrates this complexity (Friborg et al. 2003): despite being a net carbon sink, the wetland was a source of positive radiative forcing because of its emissions of $\mathrm{CH}_{4}$ (which has a warming potential 21 times larger than that of $\mathrm{CO}_{2}$ over 100 years). The case of tropical peatlands is particularly important because of high vulnerabilities driven by both land use and climate factors. The carbon store in tropical peatlands is about $70 \mathrm{PgC}$, with deposits as deep as $20 \mathrm{~m}$ (Page et al. 2002) much of which is in the southeast Asian archipelago (Indonesia, Malaysia, Papua New Guinea, Thailand, Phillipines). These peatlands have been a net $\mathrm{CO}_{2}$ sink since the late Pleistocene (Page et al. 2004). However, over the last decade, a combination of intense draining for agriculture and increasing climate variability (in the form of more intense El Niño-drought events) has resulted in a significant $\mathrm{CO}_{2}$ source with discernable effects on atmospheric $\mathrm{CO}_{2}$ 
growth. During El Niño 1997-98 events in Indonesia, burning of peat and vegetation resulted on an estimated loss of carbon between 0.81 and $2.57 \mathrm{PgC}$ in 1997 , equivalent to $13 \%$ to $40 \%$ of the mean annual global carbon emissions from fossil fuels (Page et al. 2002) and a 60\% contribution to the atmospheric $\mathrm{CO}_{2}$ growth anomaly due to fire activity (van der Werf et al. 2004).

\subsection{Vulnerabilities Associated with $\mathrm{CH}_{4}$ Exchanges}

The atmospheric methane concentration is currently about $1750 \mathrm{ppb}$ (mole fraction), having risen from around $600 \mathrm{ppb}$ in the pre-industrial era (Figure 2). The growth rate of atmospheric $\mathrm{CH}_{4}$ has declined over recent years to the point where it is now nearly zero (Allan, Lowe and Gomez 2005; Bousquet et al. 2006). The $\mathrm{CH}_{4}$ growth rate is controlled by an atmospheric methane budget which includes a number of different source and sink terms, and can be written for the present purpose as:

$$
\begin{aligned}
r_{\mathrm{CH} 4} \frac{d\left[\mathrm{CH}_{4}\right]}{d t} & =\underbrace{\left(\begin{array}{c}
F_{\text {Wetlands }}+F_{\text {Termites }}+F_{\text {Ocean }}+F_{\text {Geol }} \\
F_{\text {Fuels }}+F_{\text {Landfills }}+F_{\text {Ruminants }}+F_{\text {Rice }}+F_{\text {Fire }}+F_{\text {Other }}
\end{array}\right)}_{\text {Sources }}-\underbrace{\left(F_{\text {Trop OH }}+F_{\text {Soils }}+F_{\text {Stat }}\right)}_{\text {Sinks }} \\
\frac{d\left[\mathrm{CH}_{4}\right]}{d t} & \approx r_{\mathrm{CH} 4}^{-1} F_{\text {Sources }}-k_{\mathrm{CH} 4}\left[\mathrm{CH}_{4}\right]
\end{aligned}
$$

where $r_{\mathrm{CH} 4}$ is the mass of atmospheric methane per unit concentration and $k_{\mathrm{CH} 4}$ is an overall decay rate. The sources can be categorised as non-anthropogenic and anthropogenic (respectively grouped on the first and second lines of the "source" collection of fluxes above). Non-anthropogenic sources arise from wetlands, termites, ocean sources (including methane hydrates) and geological processes (geothermal and volcanic). Anthropogenic $\mathrm{CH}_{4}$ sources, which are amenable to mitigation, result from burning and leakage of fossil fuels (natural gas, 
petroleum, coal), landfills, ruminant livestock, rice paddies and biomass burning associated with land clearing. The largest sink is from tropospheric $\mathrm{OH}$ oxidation, with smaller sinks arising from soils, oceanic and stratospheric oxidation. The sinks can be parameterised as a first-order decay with a turnover time $\left(1 / k_{\mathrm{CH} 4}\right)$ of about 10 years. Provided $k_{\mathrm{CH} 4}$ is steady, this implies that

$$
\left[\mathrm{CH}_{4}\right](t) \approx \int_{0}^{\infty} F_{\text {Sources }}(t-s) \exp \left(-k_{\mathrm{CH} 4} s\right) d s
$$

so the $\mathrm{CH}_{4}$ concentration is a lagged moving time average of the sources with an exponential weighting factor in time.

Figure 3 shows estimates from several studies of the $\mathrm{CH}_{4}$ source and sink terms in Equation (1). Approximately $2 / 3$ of global emissions are currently from anthropogenic sources. Estimates of the sources are quite scattered, with each of the major anthropogenic sources (fossil fuels, landfills, ruminants, rice, biomass burning) contributing significantly (in the order of 50 to $100 \mathrm{TgCH}_{4} \mathrm{y}^{-1}$ ) to the total current source of about $500 \mathrm{TgCH}_{4} \mathrm{y}^{-1}$. The recent reduction in the growth rate of atmospheric $\mathrm{CH}_{4}$ to near zero (Figure 2) results from decreased fossil-fuel-related anthropogenic emissions through the 1990s, and decreased emissions since 1999 from drying wetlands in temperate and tropical Asia and tropical South America, combined with a return to rising anthropogenic emissions (Bousquet et al. 2006).

Despite the recent slow-down in $\mathrm{CH}_{4}$ growth rate, most SRES scenarios predict that atmospheric $\mathrm{CH}_{4}$ emissions will increase by a factor of typically 1.5 to 2 in the century to 2100 (with much scatter among scenarios). These predicted increased emissions result from all the anthropogenic sources listed above. In addition, future methane vulnerabilities can arise from 
mechanisms which cause either non-anthropogenic or anthropogenic $\mathrm{CH}_{4}$ sources to increase in response to climate change. Increased temperatures and atmospheric $\mathrm{CO}_{2}$ will increase $\mathrm{CH}_{4}$ production from wetlands and rice paddies as more substrate is made available. More importantly, however, is the control that the water table exercises on $\mathrm{CH}_{4}$ wetland sources. Overall increase in precipitation in a warmer climate will enhance this source by raising water tables, but regional drying trends will result in decreased $\mathrm{CH}_{4}$ production and a simultaneous increase in $\mathrm{CO}_{2}$ emissions (Christiansen et al. 2003; Cao, Gregson and Marshall 1998). This issue is similar to that for peatland and wetland drainage, discussed above for $\mathrm{CO}_{2}$ emissions.

\section{Semi-quantitative Evaluation of Carbon-Climate Vulnerabilities}

Evaluation of future carbon-climate vulnerabilities is not easy. The first requirement is a quantitative definition, here constructed as follows: we imagine a model of the carbon-climate system which includes a coupling or feedback process $P$ between carbon and climate (such as any of the processes in Table 2). Starting from a given initial state of the system, the model can be integrated forward in time to produce estimates of the state $\mathbf{x}(t)$ of the system at any future time $t$. This integration can be carried out for an "uncoupled" version of the model in which the process $P$ is omitted from the model equations, and for a "coupled" version in which $P$ is included. For a variable $y$ in the carbon-climate system such as atmospheric $\mathrm{CO}_{2}$ or temperature (or in general any function of the state vector $\mathbf{x}(t))$, the vulnerability of $y$ to $P$ at time $t$ can be defined as

$$
\delta y(t)=y_{C}(t)-y_{U}(t)
$$

where $y_{C}(t)$ and $y_{U}(t)$ are respectively the values of $y(t)$ from the coupled and uncoupled versions 
of the model. Under this quantitative definition, the vulnerability is specific to a variable $y$ (such as a carbon pool), a process $P$, and a time $t$. It is a model-based, "what-if" measure of the significance of process $P$. (This definition is not the same as the sensitivities used in $\mathrm{C}^{4} \mathrm{MIP}$ analyses, which are linearised relationships between $\delta y_{1}(t)$ and $\delta y_{2}(t)$ for different model variables $y_{1}$ and $y_{2}$, for example the sensitivity of terrestrial or ocean carbon uptake to $\mathrm{CO}_{2}$ or temperature).

In the introduction to this chapter we have already reviewed the two main ways that have been used recently to explore carbon-climate vulnerability: the judgement-based, risk-assessment approach of G2004, and fully coupled carbon-climate models as in the $\mathrm{C}^{4} \mathrm{MIP}$ experiments (Friedlingstein et al. 2006). These approaches have complementary strengths: the riskassessment approach is subjective, exploratory and largely non-quantitative. The fully coupled model approach is quantitative and rigorous (within the parameterisation choices in particular models) but is subject to the usual difficulties of complex, numerically intensive models: (1) model parameterisations (functional relationships between fluxes and model state variables) are scale-dependent (Raupach et al. 2005) and hence not unique, so that their choice involves an element of subjective judgement; (2) the settings of parameter values (numbers in the functional relationships) are usually underdetermined by available information; (3) complex models are usually numerically intensive and expensive to integrate over long times (particularly in ensemble mode to assess the properties of model solutions which are chaotic attractors), which places a practical restriction on the range of processes $(P)$ which can be assessed.

For these reasons it is appropriate to explore an intermediate pathway for assessing carbon-climate vulnerability, based on very simple but still quantitative models which preserve the essential carbon-climate feedbacks leading to possible vulnerabilities. Criteria for a simple 
model to be used in this way are that the model broadly reproduces (1) observed features of past changes in the carbon-climate system over the last 200 years, and (2) the future predictions of more complex models, such as carbon-climate trajectories under the four main classes of IPCC scenario (Table 1); (3) the model must include defensible (though necessarily simple) parameterisations of processes $(P)$ to be assessed for vulnerability which are not currently included in more complex models. The basic assumption is that although a simple model cannot provide a stand-alone prediction of the trajectory of the carbon-climate system at the same level of sophistication as a fully coupled carbon-climate model, it can provide information about the perturbation resulting from the presence or absence of a process $P$.

To illustrate this approach we have estimated the vulnerability of the carbon-climate system to one significant feedback, the carbon release from permafrost soils under the influence of warming (Zimov, Schuur and Chapin 2006). Here we assess the vulnerability due to $\mathrm{CO}_{2}$ only (recognising that this is an underestimate of the true vulnerability because of the additional effect of $\mathrm{CH}_{4}$ ) by using a simple, globally-averaged "box" carbon-climate model with the following attributes.

1. The model state vector includes six variables: mean global temperature $\left(T_{A}\right)$, atmospheric $\mathrm{CO}_{2}$ concentration $\left(\left[\mathrm{CO}_{2}\right]_{A}\right)$, the terrestrial carbon biomass excluding frozen soils $\left(C_{B}\right)$, carbon store in permafrost or frozen soils $\left(C_{F}\right)$, marine carbon store as dissolved inorganic carbon $\left(C_{M}\right)$, and partial pressure of $\mathrm{CO}_{2}$ in the upper ocean $\left(\mathrm{pCO}_{2}\right)$. Model equations and parameters are given in Tables 3 to 5 .

2. Atmospheric $\mathrm{CO}_{2}$ is connected to climate $\left(T_{A}\right)$ through an overall climate sensitivity to $\mathrm{CO}_{2}$ which parameterises not only the direct radiative forcing by $\mathrm{CO}_{2}$ increases but also all 
other associated climate feedbacks (water vapour, clouds, ...). Two alternative formulations are used, in which changes in $T_{A}$ are proportional either to changes in $\left[\mathrm{CO}_{2}\right]_{A}$ itself or to changes in $\ln \left[\mathrm{CO}_{2}\right]_{A}$ (Table 3). The latter is consistent with classical radiative transfer theory for infrared absorption in nearly saturated $\mathrm{CO}_{2}$ bands (Arrhenius 1896; Goody 1964) while the former provides some account for positive feedbacks (for example from water vapour) which cause greenhouse warming to be greater than that for $\mathrm{CO}_{2}$ alone. Each includes a single sensitivity parameter. Neither expression has a formal justification, but the differences between the two provide a first indication of the sensitivity of the carbon-climate system to assumptions about the $\mathrm{CO}_{2}$-temperature coupling.

3. Frozen-soil carbon $\left(C_{F}\right)$ is assumed to be released as $\mathrm{CO}_{2}$ under the influence of global warming, from a pool initialised at a pre-industrial value $C_{F 0}=900 \mathrm{PgC}$ (Zimov, Schuur and Chapin 2006). The rate constant for this release $\left(k_{F}\right)$ is zero in pre-industrial conditions $\left(T_{A}=T_{A 0}\right)$ and increases linearly with climate warming $\left(T_{A}-T_{A 0}\right)$ with a proportionality coefficient $k_{F T}$, so that $d C_{F} / d t=-k_{F T}\left(T_{A}-T_{A 0}\right) C_{F}$. To estimate $k_{F T}$, we use the estimate that a warming of $2 \mathrm{degC}$ will lead to shrinking of the permafrost area by around 25\% (Anisimov, Nelson and Pavlov 1999). Assuming that (1) this area decrease translates to a shrinkage of the $C_{F}$ pool by the same factor, and (2) the release occurs over 100 years, the implied value of $k_{F T}$ is 0.25 per century per $(2 \operatorname{deg} C)$ or $0.00125 \operatorname{deg} C^{-1} \mathrm{y}^{-1}$. A value of $0.001 \operatorname{degC}^{-1} \mathrm{y}^{-1}$ is used here. This is a conservative value, mainly because a warming of 2 degC is likely to occur over a shorter time than 100 years, which would increase the inferred value of $k_{F T}$.

4. Parameters (particularly the climate sensitivities to $\mathrm{CO}_{2}$ ) and initial conditions were chosen so that predictions approximately matched past (1750 to 2005) trends $T_{A}$ and $\left[\mathrm{CO}_{2}\right]_{A}$ (Table 5). 
Figure 4 shows predictions for 1750 to 2100 under four IPCC SRES scenarios (Table 1), with no frozen-carbon feedback $\left(k_{F T}=0\right)$. Agreement with past observations of $T_{A}$ and $\left[\mathrm{CO}_{2}\right]_{A}$ is satisfactory. Predictions with a linear climate sensitivity to $\mathrm{CO}_{2}$ (upper panels) yield a warming range in 2100 of $2 \operatorname{degC}$ (scenario B1) to $4 \operatorname{degC}$ (scenario A2), compared with 1.5 to $2.5 \operatorname{degC}$ from the logarithmic climate sensitivity to $\mathrm{CO}_{2}$. The former, larger warming is very close to the ensemble of climate model results in the IPCC Fourth Assessment Report (IPCC 2007), while the latter is lower. The $\left[\mathrm{CO}_{2}\right]_{A}$ range is $560 \mathrm{ppm}$ (scenario $\mathrm{B} 1$ ) to $820 \mathrm{ppm}$ (scenario A2).

Figure 5 compares model predictions with the frozen-carbon pool disabled $\left(k_{F T}=0\right)$ and enabled $\left(k_{F T}=0.001 \mathrm{degC}^{-1} \mathrm{y}^{-1}\right)$, using future emissions scenario A2 (the standard scenario for $\mathrm{C}^{4} \mathrm{MIP}$ ). With linear climate sensitivity to $\mathrm{CO}_{2}$ (which yields a model behaviour broadly consistent with IPCC predictions as noted above), the positive feedback on warming through $\mathrm{CO}_{2}$ release from frozen soils yields an additional temperature increment in $2100\left(\delta T_{A}\right)$ of about $0.7 \mathrm{degC}$ and a $\mathrm{CO}_{2}$ increment $\left(\delta\left[\mathrm{CO}_{2}\right]_{A}\right)$ of about $80 \mathrm{ppm}$, above the changes induced by other processes. The increments with the logarithmic climate sensitivity to $\mathrm{CO}_{2}$ are lower, because vulnerability of frozen carbon increases with warming.

This simple calculation neglects the additional warming due to $\mathrm{CH}_{4}$ release. From one estimate (Zimov, Schuur and Chapin 2006), about $30 \%$ of the carbon released to the atmosphere from thawing permafrost is released as $\mathrm{CH}_{4}$, with a present global warming potential (GWP) of about 21 relative to $\mathrm{CO}_{2}$ (though the GWP of $\mathrm{CH}_{4}$ will decline in the future). This methane has a residence time in the atmosphere of the order of 10 years, ultimately being oxidised to $\mathrm{CO}_{2}$. Thus the GWP of the released carbon decreases with time. 


\section{Implications of Carbon-Climate Vulnerabilities for Carbon Observation}

Over several years the global research and observation communities have been developing a concept for integrated global carbon observation. The carbon theme report of the Integrated Global Observing Strategy (Ciais et al. 2004) calls for integrated observations of fluxes, processes and pools, principally:

- satellite measurements of atmospheric-column $\mathrm{CO}_{2}, \mathrm{CH}_{4}$ and other GHGs, together with insitu (flask and continuous) measurements;

- an operational, optimised network of eddy-covariance flux towers, measuring the $\mathrm{CO}_{2}$ flux as NEE, with water and energy fluxes, over all major ecosystems;

- a global system for in-situ (ship, drifter) ocean $\mathrm{pCO}_{2}$ measurements;

- satellite observations of vegetation and other land surface properties;

- georeferenced fossil-fuel emission maps including temporal variability and uncertainties;

- regular inventories of forest above-ground biomass and soil carbon content;

- regular inventories of dissolved carbon and related biogeochemical quantities in the ocean;

- satellite and in-situ observations of fire, land cover change and other disturbance processes;

- monitoring of land-to-ocean carbon fluxes in river runoff;

- monitoring of carbon fluxes associated with goods (harvesting, trade, disposal).

Many of these measurements (particularly the atmospheric concentrations and ocean biogeochemistry) are to be integrated with near-real-time modelling frameworks, using data assimilation into climate and earth system models. This may involve collaboration with the atmosphere-ocean models run by operational weather forecasting agencies, together with longertime-scale models of pool dynamics in the carbon-climate system. 
In the introduction we highlighted two broad goals for a global carbon observing system, oriented respectively towards understanding and management. Recognition of carbon-climate vulnerabilities gives added focus to both goals, through the need to provide early warning of feedbacks (both positive and negative), to understand the reasons for emerging trends, and to provide national and international policy communities with information to manage vulnerabilities. Considering the carbon-climate vulnerabilities associated with terrestrial processes (Section 3 and Table 2), we now analyse the modes of terrestrial observation which emerge as having particular importance. Some are already well covered by existing plans, others less so. The discussion is organised around (1) fluxes and processes and (2) pools.

\subsection{Fluxes and Processes}

Additional observations are needed to increase our capacity to attribute carbon fluxes to specific source and sink processes, and to detect changes in the statistical properties of vulnerabilities associated with episodic disturbances. The following are key areas:

- Responses of NPP and respiration to extreme events: NPP and respiration respond not only to long-term climate shifts but also to extreme events (sometimes through threshold-like transitions), as has already been observed (Section 3.1). Observational requirements to improve detection and understanding of these effects include

o Satellite measurements of vegetation dynamics over multi-year periods: longevity of satellite records requires rehabilitation and harmonisation of data from old systems with records extending back to the 1980s (eg AVHRR), together with maintenance of modern systems (eg MODIS) and launching of well-equipped new systems on the time 
scales required to maintain continuity through overlap between systems.

o Process-based observations: Flux towers and other process observations have a major role in the detection and attribution of the effects of drought and heat stress on production. Consistent long-term observations are critical for this purpose, to enable the extreme-event signal to emerge from the climatological background.

- Multi-factorial of responses NPP and respiration to temperature, water, nutrients and $\mathrm{CO}_{2}$ : Climate-induced changes in the relationship between NPP and soil respiration have major implications for the terrestrial carbon balance, including NEE and pool dynamics. There is a wide scatter in existing process-based information on the responses of NPP, respiration and NEE to interactions among the drivers of temperature, water, nutrients and $\mathrm{CO}_{2}(\mathrm{C} 2007$; also see Section 3.1). It is important to attribute and hence reduce this scatter, which implies a continuing demand for ecosystem eddy flux measurements coupled with chamber-based soil measurements over diverse ecosystems (boreal, tundra, tropical, permafrost, temperate forests, semi-arid regions, etc.), together with ongoing multi-factorial manipulative experiments to disentangle the interactions.

- Deforestation: Carbon fluxes from deforestation remain the single most important direct human forcing of the terrestrial carbon balance, and the component of the global carbon budget with the largest uncertainty. To reduce this uncertainty, we need

o improved measurements of deforestation rates (including selective logging) from remote sensing;

o improved biomass densities to calculate carbon emission factors; and

o improved knowledge of the time courses of carbon fluxes following deforestation (eg 
biomass cleared in one year may be burned in following years; and there are time lags associated with soil respiration). Yearly measurements deforestation would also help to attribute annual fluctuations in atmospheric $\mathrm{CO}_{2}$ growth (current deforestation data is available only in increments of 5 or 10 years)..

- Fire: This is another key process responsible for a large part of the perturbations in the annual $\mathrm{CO}_{2}$ growth. Global improvement in estimates of both burned area and carbon emissions from fire will need to rely on atmospheric networks and remote sensing products. These observations include increased focus on (1) use of $\mathrm{CO}$ and $\mathrm{CH}_{4}$ to quantify the contribution of fires to the atmospheric $\mathrm{CO}_{2}$ growth (Langenfelds et al. 2002); (2) extraction of burned area (monthly) and hot spots (daily) from remote sensing; (3) ground and remote sensing observations of vegetation recovery after fire (when not linked to deforestation).

\subsection{Pools}

In addition to existing and currently planned inventory networks for monitoring terrestrial carbon pools, two kinds of observation emerge as critical from a vulnerability standpoint.

- Carbon in frozen soils: Section 4 has offered a semi-quantitative analysis of the significant carbon-climate vulnerability associated with carbon stored in frozen soils at high northern latitudes, which are susceptible to decomposition under global warming. To improve estimates such as this one, it is important to monitor thawing trends and the resulting carbon emission, particularly its distribution between $\mathrm{CO}_{2}$ and $\mathrm{CH}_{4}$. Key measurements are:

o monitoring of the permafrost southern limit and changes in depth of permafrost;

o carbon content in frozen soils, to full profile depth (substantially deeper than $1 \mathrm{~m}$ ); 
o measurements of vertical fluxes of $\mathrm{CO}_{2}$ and $\mathrm{CH}_{4}$ with eddy covariance (local) and atmospheric-inverse (large regional) methods;

o measurement of lateral carbon fluxes to rivers and the coastal zone.

- Peatlands: Both in high latitudes (as a continuum of permafrost) and in the tropics, peatlands require careful monitoring of changes in stocks and fluxes under the influences of warming and changes in the hydrological cycle. Particularly in the tropics, changes in hydrological regime result both from climate change and also from human activities such as drainage. Key measurements (similar to those for frozen soils) include

o monitoring of tropical peatland deforestation and drainage;

o carbon content to full profile depth (substantially deeper than $1 \mathrm{~m}$ );

o monitoring of vertical and lateral fluxes in both cold and tropical peatlands;

o monitoring of subsidence rates of drained peatland forests.

\section{Conclusion}

In Section 3 we identified several major carbon-climate vulnerabilities: limitation of $\mathrm{CO}_{2}$ fertilisation by water and nutrient constraints; the response of soil respiration and NPP to warming and moisture; permafrost thawing; fire; and ecosystem responses to a variety of land use changes. A semi-quantitative assessment in Section 4 of just one of these vulnerabilities (the $\mathrm{CO}_{2}$ consequence of permafrost thawing) suggests a perturbation on global $\mathrm{CO}_{2}$ in 2100 of about $80 \mathrm{ppm}$ and a temperature perturbation of about $0.7 \mathrm{degC}$, relative to a prediction under the $\mathrm{A} 2$ emissions scenario in which this positive feedback is absent. The temperature perturbation is a conservative estimate because of the neglect of warming due to $\mathrm{CH}_{4}$. It is reasonable to conclude 
that the sum of all the vulnerabilities discussed in Section 3 is not negligible relative to the primary forcing of the climate system by anthropogenic $\mathrm{CO}_{2}$. The implication for carbon observation is to focus attention on the process measurements and monitoring programs needed to track and better quantify the feedback processes leading to these vulnerabilities.

Acknowledgments: The work described here is a contribution to Theme 2 (Processes and Interactions) of the Global Carbon Project (www.globalcarbonproject.org). We are grateful to Cathy Trudinger and Will Steffen for constructive comments on drafts of this work, and Peter Briggs for assistance with figures. MRR thanks the CarboEurope Integrated Program for support to attend the CarboEurope Greenhouse Gas Workshop, Amsterdam, 4-5 April 2005, which prompted the writing of this chapter. We thank the Australian Greenhouse Office and CSIRO for supporting the GCP International Project Office in Canberra. 


\section{Table Captions}

Table 1: Indicative fossil fuel emissions of $\mathrm{CO}_{2}$ under four major IPCC SRES emissions scenarios (Nakicenovic et al. 2000). There are three variants of the A1 (globalised, economically oriented) scenario: A1B (balanced), A1T (technologically innovative) and A1FI (fossil-fuel intensive), leading to very different emissions trajectories. Only the A1B scenario is used here.

Table 2: Processes contributing to net land-atmosphere exchange of $\mathrm{CO}_{2}$. Drivers are ( $a$, shaded grey) changes in atmospheric composition and chemistry; ( $b$, unshaded) physical climate changes; ( $c$, shaded grey) changes in land use and land management. The sign of the land-to-air $\mathrm{CO}_{2}$ flux is the same as the sign of the climate warming feedback (a positive land-to-air flux increases the $\mathrm{CO}_{2}$ radiative forcing).

Table 3: Governing equations for state variables in a simple box model of the carbon-climate system. Carbon fluxes $(F)$ are defined in Table 4; parameters are defined in Table 5.

Table 4: Phenomenological equations for fluxes $(F)$ in a simple box model of the carbon-climate system.

Table 5: Parameters in a simple box model of the carbon-climate system. 


\section{Figure Captions}

Figure 1: The global carbon budget for the period 1950-2005, showing terms in the $\mathrm{CO}_{2}$ mass balance: [atmospheric $\mathrm{CO}_{2}$ accumulation $]=$ [emission flux from fossil fuels $]+[$ other industrial emissions $]+$ [emissions from land use change] - [flux to terrestrial sink] - [flux to ocean sink] Data sources as in Canadell et al. 2007a, with atmospheric $\mathrm{CO}_{2}$ change from ice core data (Law Dome, Antarctica; Etheridge et al. 1998b) before 1959 and direct measurements (Keeling and Whorf 2005) after 1959. Net terrestrial uptake is inferred by difference (total emissions less ocean uptake).

Figure 2: Atmospheric $\mathrm{CH}_{4}$ concentrations from ice core data from Law Dome, Antarctica, and Summit, Greenland (Etheridge et al. 1998a); the Cape Grim Air archive (Etheridge et al. 1998a); and flask measurements at Cape Grim, Tasmania, and Mauna Loa, Hawaii (CSIRO flask network, archived at http://cdiac.ornl.gov/trends/atm_meth/csiro/csiro_gaslabch4.html). Upper and lower panels show data on 1000-year and 50-year time axes, respectively.

Figure 3: Estimates of sources (upper panel) and sinks (lower panel) in the global atmospheric methane budget. Note different scales. References: Fung et al. 1991 (F91); Hein, Crutzen and Heimann 1997 (H97); Lelieveld, Crutzen and Dentener 1998 (L98); Houweling et al. 1999 (H99); Mosier et al. 1998 (M98); Olivier et al. 1999 (O99); Cao, Gregson and Marshall 1998 (C98); Wuebbles and Hayhoe 2002 (W2002); Bogner and Matthews 2003 (B2003); Mikaloff Fletcher et al. 2004a; Mikaloff Fletcher et al. 2004b (M2004); Wang et al. 2004 et al. 2004 (W2004); Chen and Prinn 2005 (CP2005). A 4-level greyscale is used to distinguish studies, cycling 3 times through the 12 available studies. 
Figure 4: Predictions from a simple box model of the carbon-climate system of atmospheric $\mathrm{CO}_{2}$ concentration $\left(\left[\mathrm{CO}_{2}\right]_{A}\right.$, left panels) and global mean temperature $\left(T_{A}\right.$, right panels). The zero line for $T_{A}$ is set to the average observed $T_{A}$ over the period 1961 to 1990 . Four emissions scenarios are shown, comprising actual fossil-fuel and land-use-change emissions from 1751 to 2005 (data sources as in Figure 1), and the A2 (solid), A1B (short dashed), B1 (medium dashed) and B2 (long dashed) scenarios (Nakicenovic et al. 2000) from 2005 to 2100 . Upper and lower panels respectively show predictions with linear and logarithmic climate sensitivities to $\left[\mathrm{CO}_{2}\right]_{A}$. Data (points) for $\left[\mathrm{CO}_{2}\right]_{A}$ are composite observations from ice core data from Law Dome, Antarctica (Etheridge et al. 1998b) (before 1959) and direct atmospheric measurements at Mauna Loa, Hawaii (Keeling and Whorf 2005) (1959 onward). Data (points) for $T_{A}$ are the global temperature series 1850-2004 (Jones et al. 2006).

Figure 5: Predictions from a simple box model of the carbon-climate system of atmospheric $\mathrm{CO}_{2}$ concentration $\left(\left[\mathrm{CO}_{2}\right]_{A}\right.$, left panels) and global mean temperature ( $T_{A}$, right panels) without (solid) and with (dashed) feedbacks between the frozen carbon pool and global temperature. The emissions scenario comprises actual fossil-fuel and land-use-change emissions from 1751 to 2005 (data sources as in Figure 1), and the A2 scenario from 2005 to 2100 . Upper and lower panels respectively show predictions with linear and logarithmic climate sensitivities to $\left[\mathrm{CO}_{2}\right]_{A}$. Data for $\left[\mathrm{CO}_{2}\right]_{A}$ and $T_{A}$ as in Figure 4. 


\section{Tables and Figures}

\begin{tabular}{|c|c|c|c|c|}
\hline Scenario & $\begin{array}{c}\text { Global- } \\
\text { local } \\
\text { orientation }\end{array}$ & $\begin{array}{c}\text { Economic- } \\
\text { environmental } \\
\text { orientation }\end{array}$ & $\begin{array}{c}\text { Fossil Fuel Emission } \\
\left(\mathbf{P g C ~}^{-\mathbf{1}}\right) \mathbf{~ i n ~ 2 0 5 0}\end{array}$ & $\begin{array}{c}\text { Fossil Fuel Emission } \\
\left.\mathbf{( P g C ~} \mathbf{~}^{-1}\right) \mathbf{~ i n ~ 2 1 0 0}\end{array}$ \\
\hline A1B & Global & Economic & 17 & 15 \\
\hline A2 & Regional & Economic & 15 & 30 \\
\hline B1 & Global & Environmental & 11 & 15 \\
\hline B2 & Regional & Environmental & 12 & 7 \\
\hline
\end{tabular}

Table 1: Indicative fossil fuel emissions of $\mathrm{CO}_{2}$ under four major IPCC SRES emissions scenarios (Nakicenovic et al. 2000). There are three variants of the A1 (globalised, economically oriented) scenario: A1B (balanced), A1T (technologically innovative) and A1FI (fossil-fuel intensive), leading to very different emissions trajectories. Only the A1B scenario is used here. 


\begin{tabular}{|l|l|c|c|}
\hline & \multicolumn{1}{|c|}{ Process } & Driver & $\begin{array}{c}\text { Sign of land-to-air flux } \\
(+,-)=(\text { source, sink) }\end{array}$ \\
\hline$a 1$ & CO2 fertilisation & $a$ & - \\
\hline$a 2$ & Nutrient constraints on $\mathrm{CO}_{2}$ fertilisation & $a$ & + \\
\hline$a 3$ & Fertilisation by nitrogen deposition & $a$ & - \\
\hline$a 4$ & Effects of pollution (eg acid rain, ozone, ...) & $a$ & + \\
\hline$b 1$ & Response of respiration to warming and moisture & $b$ & + (warming); \pm (moisture) \\
\hline$b 2$ & Response of NPP to warming and moisture & $b$ & - (warming); \pm (moisture) \\
\hline$b 3$ & Radiation effects (eg direct/diffuse partition) & $b$ & - \\
\hline$b 4$ & Biome shifts & $b$ & \pm \\
\hline$b 5$ & Permafrost thawing & $b$ & + \\
\hline$b 6$ & Changes in wildfire regime & $b$ & + (rapid),- (slow) \\
\hline$b 7$ & Changes in herbivore (eg insect) ecology & $b, c$ & + \\
\hline$c 1$ & Changes in managed fire regime & $c$ & + (rapid),, (slow) \\
\hline$c 2$ & Managed reforestation and afforestation & $c$ & - \\
\hline$c 3$ & $\begin{array}{l}\text { Unmanaged forest regrowth (after cropland } \\
\text { abandonment) }\end{array}$ & $c$ & - \\
\hline c4 & Woody encroachment / woody thickening & $c$ & - \\
\hline$c 5$ & $\begin{array}{l}\text { Deforestation and land clearing (eg forest to } \\
\text { savannah) }\end{array}$ & $c$ & + \\
\hline$c 6$ & Peatland and wetland drainage & $c$ & + \\
\hline$c 7$ & Agricultural practices & $c$ & + \\
\hline
\end{tabular}

Table 2: Processes contributing to net land-atmosphere exchange of $\mathrm{CO}_{2}$. Drivers are ( $a$, shaded grey) changes in atmospheric composition and chemistry; ( $b$, unshaded) physical climate changes; ( $c$, shaded grey) changes in land use and land management. The sign of the land-to-air $\mathrm{CO}_{2}$ flux is the same as the sign of the climate warming feedback (a positive land-to-air flux increases the $\mathrm{CO}_{2}$ radiative forcing). 


\begin{tabular}{|c|c|c|}
\hline \multicolumn{2}{|l|}{ State variable } & Governing equation \\
\hline $\begin{array}{l}\text { Mean global temperature } \\
(\operatorname{deg} C)\end{array}$ & $T_{A}$ & 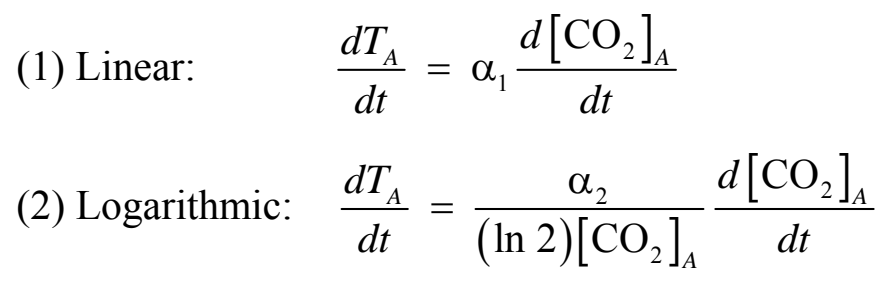 \\
\hline $\begin{array}{l}\text { Atmospheric } \mathrm{CO}_{2} \\
\text { concentration (ppm) }\end{array}$ & {$\left[\mathrm{CO}_{2}\right]_{A}$} & $r_{\mathrm{CO} 2} \frac{d\left[\mathrm{CO}_{2}\right]_{A}}{d t}=F_{F o s s}+F_{L U C}+F_{M A}+F_{F A}-\frac{d C_{B}}{d t}$ \\
\hline $\begin{array}{l}\text { Terrestrial carbon store in } \\
\text { biomass and soils }(\operatorname{PgC}) \\
\text { excluding peatlands, } \\
\text { frozen soils }\end{array}$ & $C_{B}$ & $\frac{d C_{B}}{d t}=F_{N P P}-F_{R}-F_{L U C}$ \\
\hline $\begin{array}{l}\text { Ocean (marine) carbon } \\
\text { store }(\operatorname{PgC})\end{array}$ & $C_{M}$ & $\frac{d C_{M}}{d t}=-F_{M A}$ \\
\hline Ocean $\mathrm{pCO}_{2}(\mathrm{~Pa})$ & $\mathrm{pCO}_{2}$ & $\frac{d \mathrm{pCO}_{2}}{d t}=\beta \frac{\mathrm{pCO}_{2}}{C_{M}} \frac{d C_{M}}{d t}$ \\
\hline $\begin{array}{l}\text { Carbon store in permafrost } \\
\text { (frozen soils) (PgC) }\end{array}$ & $C_{F}$ & $\frac{d C_{F}}{d t}=-F_{F A}$ \\
\hline
\end{tabular}

Table 3: Governing equations for state variables in a simple box model of the carbon-climate system. Carbon fluxes $(F)$ are defined in Table 4; parameters are defined in Table 5. 


\begin{tabular}{|l|l|l|}
\hline \multicolumn{2}{|c|}{ Carbon flux (PgC y $\left.\mathbf{y}^{-1}\right)$} & \multicolumn{1}{c|}{ Phenomenological equation } \\
\hline $\begin{array}{l}\mathrm{CO}_{2} \text { emissions from fossil } \\
\text { fuels and other industry }\end{array}$ & $F_{F o s s}$ & $\begin{array}{l}1751 \text { to 2005: data (Marland, Boden and Andres 2006) } \\
\text { future to 2100: scenarios (Table 1) }\end{array}$ \\
\hline $\begin{array}{l}\text { Emissions from land use } \\
\text { change }\end{array}$ & $F_{L U C}$ & $\begin{array}{l}1751 \text { to 2005: data (Houghton 1999, C2007) } \\
\text { future to 2100: linear decline to 0 in 2100 }\end{array}$ \\
\hline Terrestrial NPP & $F_{N P P}$ & $\begin{array}{l}F_{N P P}=F_{N P P 0}+\left(F_{N P P 2}-F_{N P P 0}\right) f\left(C_{A}-C_{A 0}, C_{A 1}-C_{A 0}\right) \\
\text { with } f(x, a)=x^{2} /\left(x^{2}+a^{2}\right), C_{A}=r_{\mathrm{CO} 2}\left[\mathrm{CO}_{2}\right]_{A}\end{array}$ \\
\hline Terrestrial respiration & $F_{R}$ & $F_{R}=k_{B 0} C_{B} 2^{\left(T_{A}-T_{A 0}\right) / \delta_{2 T}}$ \\
\hline Ocean-air $\mathrm{CO}_{2}$ flux & $F_{M A}$ & $F_{M A}=\left\{A_{O c e a n} v_{P i s t o n}\left(\left[\mathrm{pCO}_{2}\right]_{M}-\left[\mathrm{pCO}_{2}\right]_{A}\right)\right\} / k_{\text {Henry }}$ \\
\hline Permafrost-air $\mathrm{CO}_{2}$ flux & $F_{F A}$ & $F_{F A}=k_{F T}\left(T_{A}-T_{A 0}\right) C_{F}$ \\
\hline
\end{tabular}

Table 4: Phenomenological equations for fluxes $(F)$ in a simple box model of the carbon-climate system. 


\begin{tabular}{|c|c|c|}
\hline Parameter & Symbol & Value \\
\hline Conversion for atmospheric $\mathrm{CO}_{2}$ (ppm to $\mathrm{PgC}$ ) & $r_{\mathrm{CO} 2}$ & $2.181 \mathrm{PgC} \mathrm{ppm}^{-1}$ \\
\hline Linear climate sensitivity to $C_{A}$ & $\alpha_{1}$ & $0.008 \operatorname{deg} \mathrm{Cppm}^{-1}$ \\
\hline Logarithmic $\left(\mathrm{CO}_{2}\right.$ doubling) climate sensitivity to $\mathrm{CO}_{2}$ & $\alpha_{2}$ & $2 \operatorname{deg} \mathrm{C}$ \\
\hline Revelle buffer factor for response of $\mathrm{pCO}_{2}$ to $C_{M}$ & B & 12 (dimensionless) \\
\hline Initial (pre-industrial) temperature & $T_{A 0}$ & $15 \operatorname{deg} \mathrm{C}$ \\
\hline Initial (pre-industrial) $\mathrm{CO}_{2}$ concentration & {$\left[\mathrm{CO}_{2}\right]_{A 0}$} & $278 \mathrm{ppm}$ \\
\hline Initial (pre-industrial) terrestrial biomass $\mathrm{C}$ store & $C_{B 0}$ & calculated (equilibrium) \\
\hline Initial (pre-industrial) marine $\mathrm{C}$ store & $C_{M 0}$ & $5000 \mathrm{PgC}$ \\
\hline Initial (pre-industrial) ocean $\mathrm{pCO}_{2}$ & $\mathrm{pCO}_{2(0)}$ & calculated (equilibrium) \\
\hline Initial (pre-industrial) $\mathrm{C}$ store in frozen soils & $C_{F 0}$ & $500 \mathrm{PgC}$ \\
\hline Initial (pre-industrial) NPP & $F_{N P P 0}$ & $60 \mathrm{PgC}^{-1}$ \\
\hline NPP at saturation with respect to $\mathrm{CO}_{2}$ & $F_{N P P 2}$ & $75 \mathrm{PgC}^{-1}$ \\
\hline $\mathrm{CO}_{2}$ scale for NPP saturation with respect to $\mathrm{CO}_{2}$ & {$\left[\mathrm{CO}_{2}\right]_{A 1}$} & $450 \mathrm{ppm}$ \\
\hline Turnover rate for terrestrial respiration at $T_{A}=T_{A 0}$ & $k_{B 0}$ & $0.02 \mathrm{y}^{-1}$ \\
\hline Doubling temperature for $F_{R}$ & $\delta_{2 T}$ & $15 \operatorname{deg} \mathrm{C}$ \\
\hline Ocean area & $A_{\text {Ocean }}$ & $3.6 \times 10^{14} \mathrm{~m}^{2}$ \\
\hline Ocean exchange (piston) velocity & $v_{\text {Piston }}$ & $1500 \mathrm{~m} \mathrm{y}^{-1}$ \\
\hline Henry's law constant for $\mathrm{CO}_{2}$ & $k_{\text {Henry }}$ & $\begin{array}{l}2900 \times 2^{\wedge}\left(\left(25-T_{A}\right) / 25\right) \\
\mathrm{Pa} \mathrm{m}^{3} \mathrm{~mol}^{-1}\end{array}$ \\
\hline Rate per $\operatorname{deg} \mathrm{C}$ for $\mathrm{C}$ flux from frozen soils & $k_{F T}$ & 0 or $0.001 \mathrm{y}^{-1} \mathrm{deg} \mathrm{C}^{-1}$ \\
\hline
\end{tabular}

Table 5: Parameters in a simple box model of the carbon-climate system. 

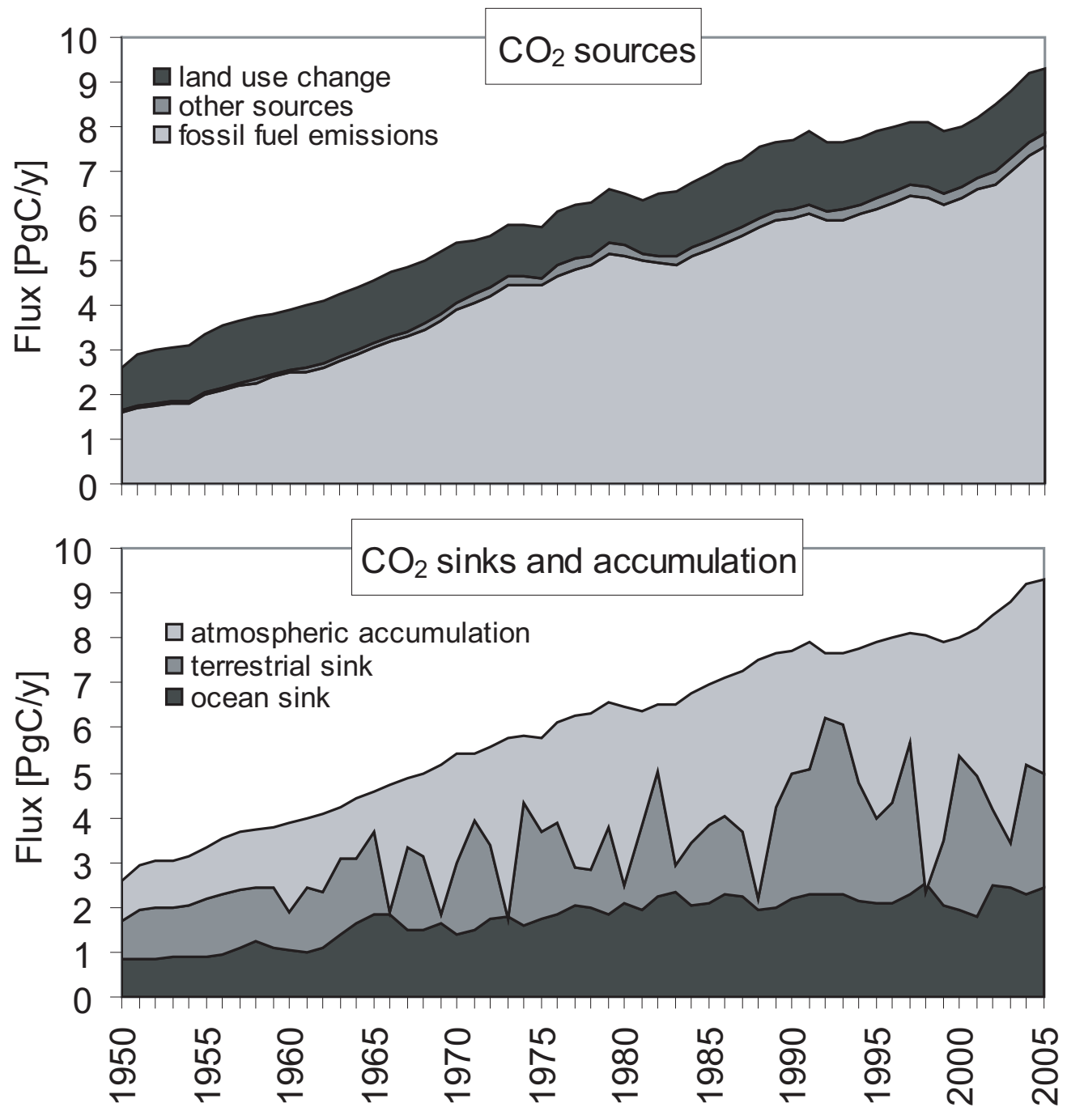

Figure 1: The global carbon budget for the period 1950-2005, showing terms in the $\mathrm{CO}_{2}$ mass balance: [atmospheric $\mathrm{CO}_{2}$ accumulation] $=$ [emission flux from fossil fuels] + [other industrial emissions] + [emissions from land use change] - [flux to terrestrial sink] - [flux to ocean sink]. Data sources as in Canadell et al. 2007a, with atmospheric $\mathrm{CO}_{2}$ change from ice core data (Law Dome, Antarctica; Etheridge et al. 1998b) before 1959 and direct measurements (Keeling and Whorf 2005) after 1959. Net terrestrial uptake is inferred by difference (total emissions less ocean uptake). 

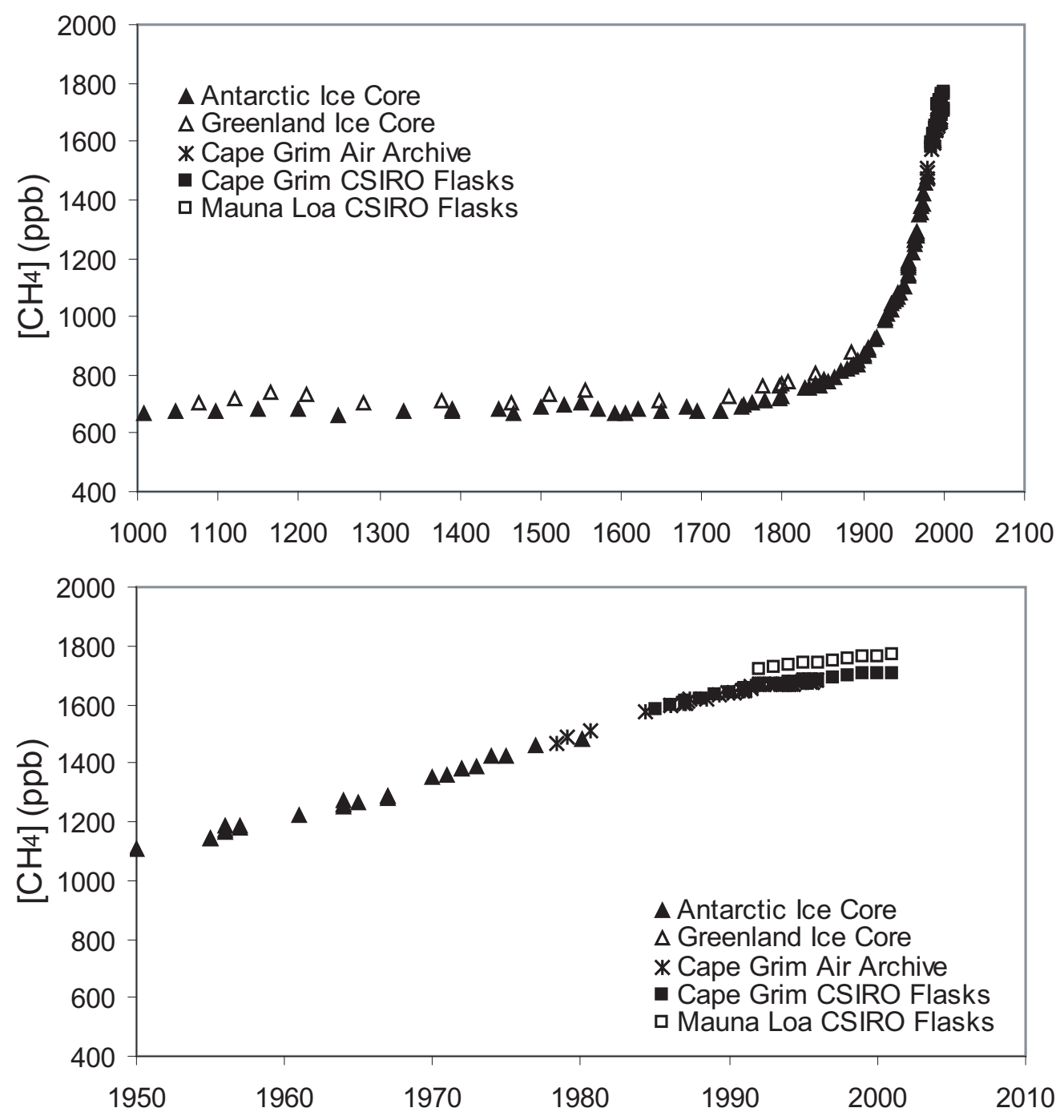

Figure 2: Atmospheric $\mathrm{CH}_{4}$ concentrations from ice core data from Law Dome, Antarctica, and Summit, Greenland (Etheridge et al. 1998a); the Cape Grim Air archive (Etheridge et al. 1998a); and flask measurements at Cape Grim, Tasmania, and Mauna Loa, Hawaii (CSIRO flask network, archived at http://cdiac.ornl.gov/trends/atm_meth/csiro/csiro_gaslabch4.html). Upper and lower panels show data on 1000-year and 50-year time axes, respectively. 

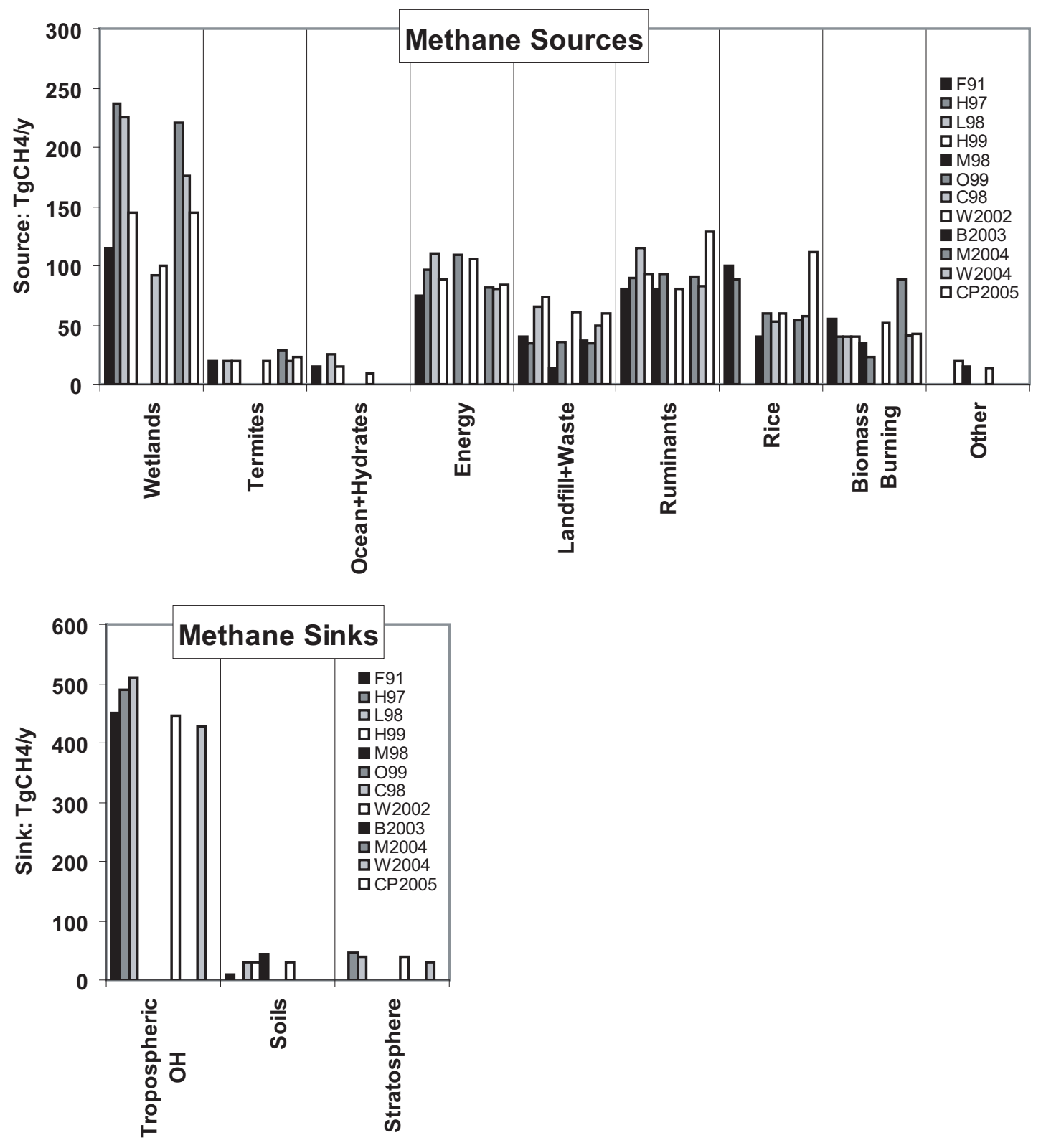

Figure 3: Estimates of sources (upper panel) and sinks (lower panel) in the global atmospheric methane budget. Note different scales. References: Fung et al. 1991 (F91); Hein, Crutzen and Heimann 1997 (H97); Lelieveld, Crutzen and Dentener 1998 (L98); Houweling et al. 1999 (H99); Mosier et al. 1998 (M98); Olivier et al. 1999 (O99); Cao, Gregson and Marshall 1998 (C98); Wuebbles and Hayhoe 2002 (W2002); Bogner and Matthews 2003 (B2003); Mikaloff Fletcher et al. 2004a; Mikaloff Fletcher et al. 2004b (M2004); Wang et al. 2004 et al. 2004 (W2004); Chen and Prinn 2005 (CP2005). A 4-level greyscale is used to distinguish studies, cycling 3 times through the 12 available studies. 

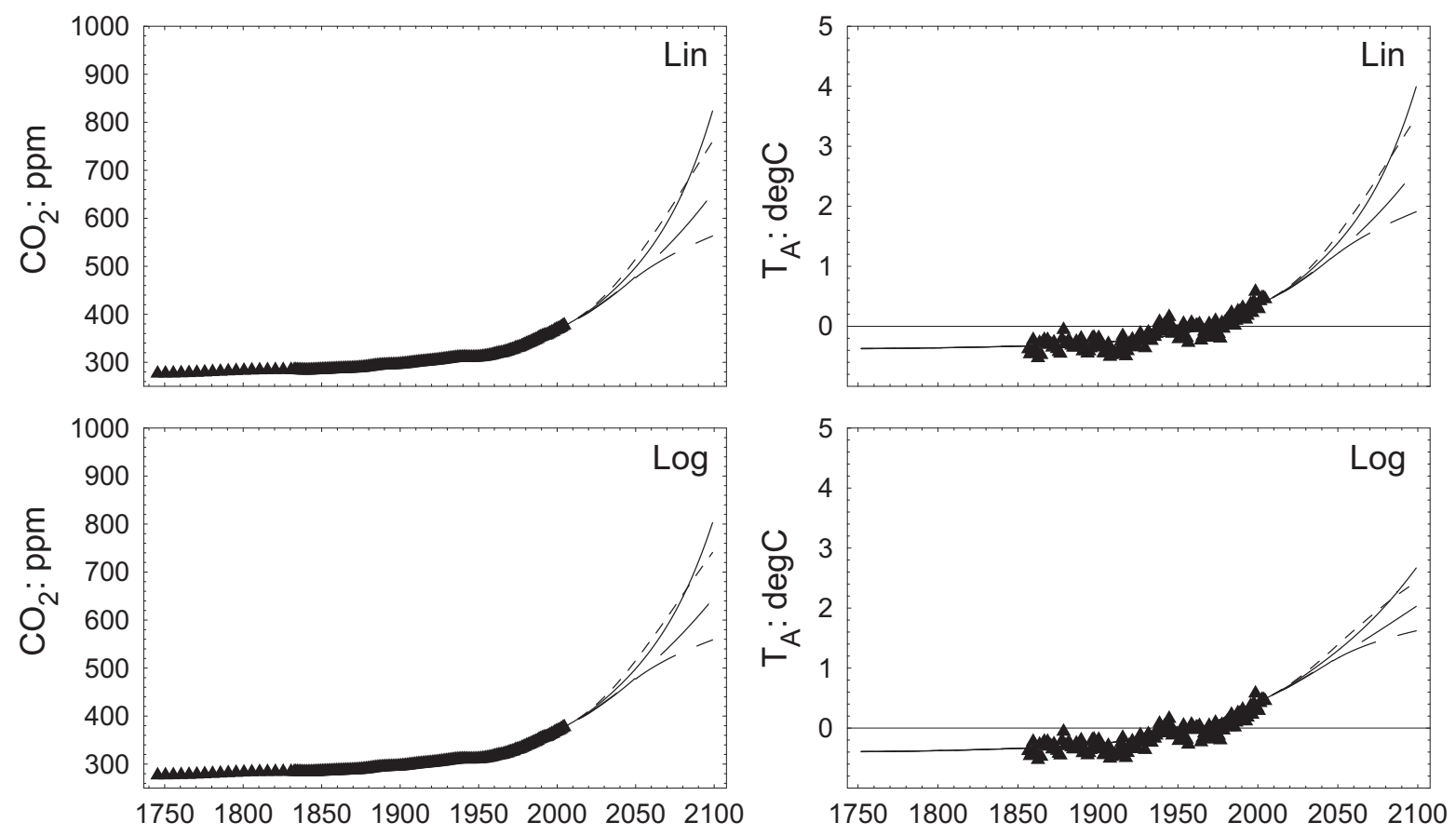

Figure 4: Predictions from a simple box model of the carbon-climate system of atmospheric $\mathrm{CO}_{2}$ concentration $\left(\left[\mathrm{CO}_{2}\right]_{A}\right.$, left panels) and global mean temperature $\left(T_{A}\right.$, right panels). The zero line for $T_{A}$ is set to the average observed $T_{A}$ over the period 1961 to 1990 . Four emissions scenarios are shown, comprising actual fossil-fuel and land-use-change emissions from 1751 to 2005 (data sources as in Figure 1), and the A2 (solid), A1B (short dashed), B1 (medium dashed) and B2 (long dashed) scenarios (Nakicenovic et al. 2000) from 2005 to 2100 . Upper and lower panels respectively show predictions with linear and logarithmic climate sensitivities to $\left[\mathrm{CO}_{2}\right]_{A}$. Data (points) for $\left[\mathrm{CO}_{2}\right]_{A}$ are composite observations from ice core data from Law Dome, Antarctica (Etheridge et al. 1998b) (before 1959) and direct atmospheric measurements at Mauna Loa, Hawaii (Keeling and Whorf 2005) (1959 onward). Data (points) for $T_{A}$ are the global temperature series 1850-2004 (Jones et al. 2006). 

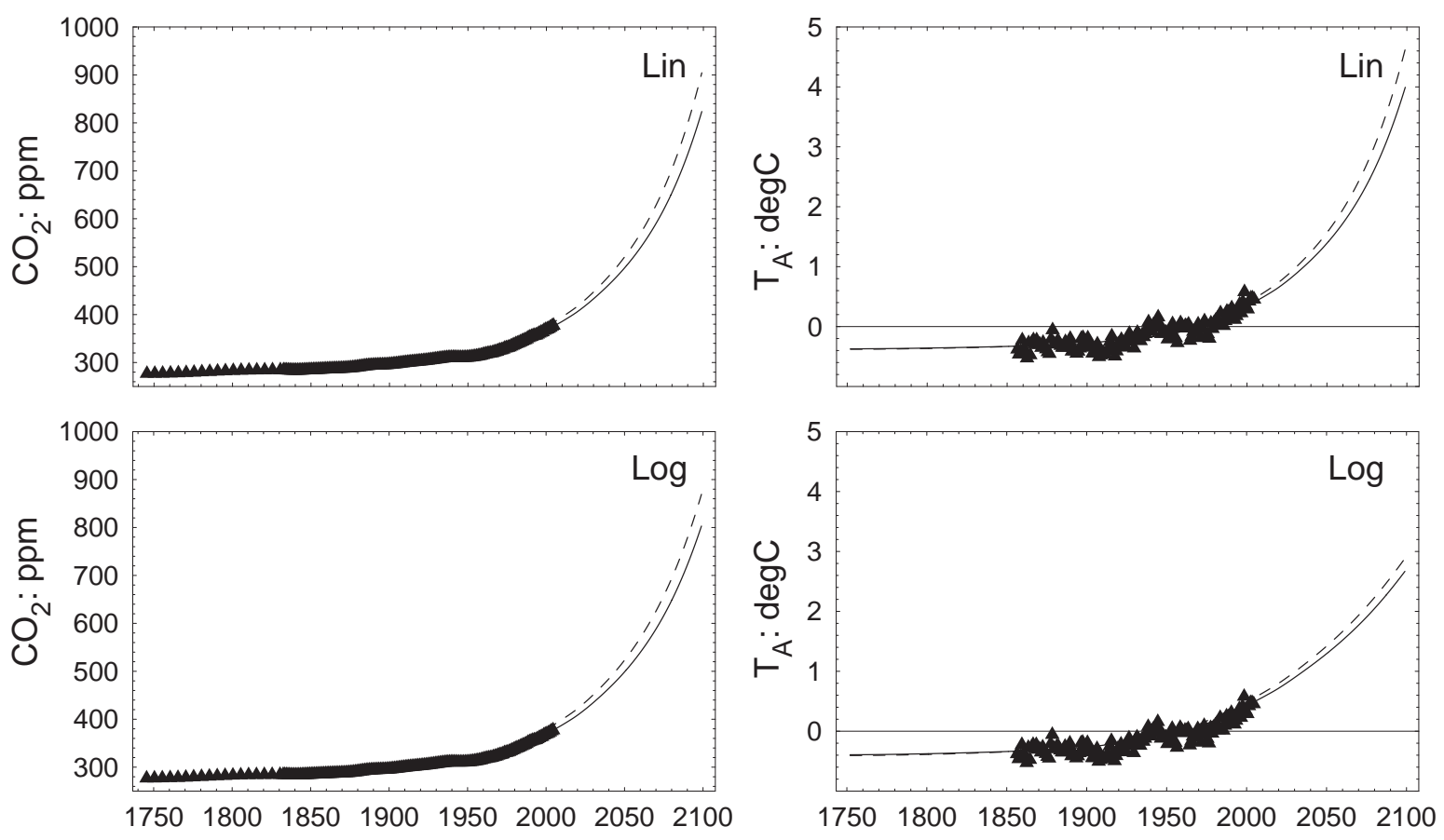

Figure 5: Predictions from a simple box model of the carbon-climate system of atmospheric $\mathrm{CO}_{2}$ concentration $\left(\left[\mathrm{CO}_{2}\right]_{A}\right.$, left panels) and global mean temperature $\left(T_{A}\right.$, right panels) without (solid) and with (dashed) feedbacks between the frozen carbon pool and global temperature. The emissions scenario comprises actual fossil-fuel and land-use-change emissions from 1751 to 2005 (data sources as in Figure 1), and the A2 scenario from 2005 to 2100 . Upper and lower panels respectively show predictions with linear and logarithmic climate sensitivities to $\left[\mathrm{CO}_{2}\right]_{A}$. Data for $\left[\mathrm{CO}_{2}\right]_{A}$ and $T_{A}$ as in Figure 4. 


\section{References}

Achard F., Eva H. D., Mayaux P., Stibig H. J., Belward A. 2004. Improved estimates of net carbon emissions from land cover change in the tropics for the 1990s. Global Biogeochem.Cycles 18: doi:10.1029/2003GB002142.

Allan W., Lowe D. C., Gomez A. J. 2005. Interannual variations of 13C in tropospheric methane: Implication for a possible atomic chlorine sink in the marine boundary layer. J.Geophys.Res. 110: doi:10.1029/2004JD005650.

Angert A., Biraud S., Bonfils C. et al. 2005. Drier summers cancel out the CO2 uptake enhancement induced by warmer springs. Proc.Natl.Acad.Sci.U.S.A. 102: 10823-10827.

Anisimov O. A., Nelson F. E., Pavlov A. V. 1999. Predictive scenarios of permafrost development under conditions of global climate change in the XXI century. Earth Cryology 3: 15-25.

Arrhenius S. 1896. On the influence of carbonic acid in the air upon the temperature of the ground. Philosophical Magazine and the Journal of Science 5: 239-276.

Bogner J., Matthews E. 2003. Global methane emissions from landfills: New methodology and annual estimates 1980-1996. Global Biogeochem.Cycles 17: doi:10.1029/2002GB001913.

Bousquet P., Ciais P., Miller J. B. et al. 2006. Contribution of anthropogenic and natural sources to atmospheric methane variability. Nature 443: 439-443.

Burrows W. H., Henry B. K., Back P. V. et al. 2002. Growth and carbon stock change in eucalypt woodlands in northeast Australia: ecological and greenhouse sink implications. Global Change Biol. 8: 769-784.

Camill P. 2005. Permafrost thaw accelerates in boreal peatlands during late-20th century climate warming. Climatic Change 68: 135-152.

Canadell J. G., Le Quere C., Raupach M. R. et al. 2007a. Increase in atmospheric CO2 growth rate caused by a changing global carbon cycle. Science Submitted. 
Canadell J. G., Pataki D., Gifford R. M. et al. 2007b. Saturation of the terrestrial carbon sink. In Terrestrial Ecosystems in a Changing World, eds. J. G. Canadell, D. Pataki, L. Pitelka, pp. 59-78. Springer-Verlag, Berlin.

Cao M. K., Gregson K., Marshall S. 1998. Global methane emission from wetlands and its sensitivity to climate change. Atmos.Environ. 32: 3293-3299.

Chen Y.-H., Prinn R. G. 2005. Atmospheric modeling of high- and low-frequency methane observations: Importance of interannually varying transport. J.Geophys.Res. 110: D10303, doi:10.1029/2004JD005542.

Christiansen T. R., Ekberg A., Ström L., Mastepanov M. 2003. Factors controlling large scale variations in methane emission from wetlands. Geophys.Res.Lett. 30: doi: 10.1029/2002GL016848.

Ciais P., Moore B. I., Steffen W. et al. 2004. Integrated global carbon observation theme: a strategy to realise a coordinated system of integrated global carbon cycle observations. Integrated Global Observing Strategy, Stockholm.

Ciais P., Reichstein M., Viovy N. et al. 2005. Europe-wide reduction in primary productivity caused by the heat and drought in 2003. Nature 437: 529-533.

Cramer W., Bondeau A., Woodward F. I. et al. 2001. Global response of terrestrial ecosystem structure and function to $\mathrm{CO} 2$ and climate change: results from six dynamic global vegetation models. Global Change Biol. 7: $357-373$.

DeFries R. S., Field C. B., Fung I. Y., Collatz G. J., Bounoua L. 1999. Combining satellite data and biogeochemical models to estimate global effects of human-induced land cover change on carbon emissions and primary productivity. Global Biogeochem.Cycles 13: 803-815.

DeFries R. S., Houghton R. A., Hansen M. C., Field C. B., Skole D., Townshend J. 2002. Carbon emissions from tropical deforestation and regrowth based on satellite observations for the 1980s and 1990s.

Proc.Natl.Acad.Sci.U.S.A. 99: 14256-14261.

Etheridge D. M., Steele L. P., Francey R. J., Langenfelds R. L. 1998a. Atmospheric methane between 1000 AD and present: Evidence of anthropogenic emissions and climatic variability. J.Geophys.Res. 103: 15979-15993. 
Etheridge D. M., Steele L. P., Langenfelds R. L., Francey R. J., Barnola J. M., and Morgan V. I. 1998b. Historical CO2 records from the Law Dome DE08, DE08-2, and DSS ice cores. Trends: A Compendium of Data on Global Change, Carbon Dioxide Information Analysis Center, Oak Ridge National Laboratory, U.S. Department of Energy, Oak Ridge, Tennessee, USA.

Fang C. M., Smith P., Moncrieff J. B., Smith J. U. 2005. Similar response of labile and resistant soil organic matter pools to changes in temperature. Nature 433: 57-59.

Fang J. Y., Chen A. P., Peng C. H., Zhao S. Q., Ci L. 2001. Changes in forest biomass carbon storage in China between 1949 and 1998. Science 292: 2320-2322.

Farquhar G. D., Caemmerer von S., Berry J. A. 1980. A biochemical model of photosynthetic $\mathrm{CO}_{2}$ assimilation in leaves of $\mathrm{C}_{3}$ species. Planta 149: 78-90.

Farquhar G. D., Sharkey T. D. 1982. Stomatal conductance and photosynthesis. Annu.Rev.Plant Physiol. 33: 317345.

Field C. B., Chapin III F. S., Chiariello N. R., Holland E. A., Mooney H. A. 1996. The Jasper Ridge CO2 experiment: Design and motivation. In Carbon Dioxide and Terrestrial Ecosystems, eds. G. W. Koch, H. A. Mooney, pp. 121-145. Academic Press, San Diego.

Field C. B., Raupach M. R. 2004. The Global Carbon Cycle: Integrating Humans, Climate, and the Natural World. Island Press, Washington, $526 \mathrm{pp}$.

Friborg T., Soegaard H., Christensen T. R., Lloyd C. R., Panikov N. S. 2003. Siberian wetlands: Where a sink is a source. Geophys.Res.Lett. 30.

Friedlingstein P., Cox P., Betts R. et al. 2006. Climate-carbon cycle feedback analysis: Results from the C4MIP model intercomparison. J.Climate 19: 3337-3353.

Fung I. Y., John J., Lerner J., Mathews E., Prather M., Steele L. P., Fraser P. J. 1991. Three-dimensional model synthesis of the global methane cycle. J.Geophys.Res. 96: 13033-13065. 
Giardina C. P., Ryan M. G. 2000. Biogeochemistry - Soil warming and organic carbon content - Reply. Nature 408: 790.

Gifford R. M., Howden M. 2001. Vegetation thickening in an ecological perspective: significance to national greenhouse gas inventories. Environmental Science and Policy 4: 59-72.

Global Carbon Project 2003. Science Framework and Implementation. Earth System Science Partnership (IGBP, IHDP, WCRP, Diversitas) Report No. 1; GCP Report No. 1, Global Carbon Project, Canberra.

Goody R. M. 1964. Atmospheric Radiation. I. Theoretical Basis. Clarendon Press, Oxford, 436 pp.

Greenblatt J. B., Sarmiento J. L. 2004. Variability and climate feedback mechanisms in ocean uptake of CO2. In The Global Carbon Cycle: Integrating Humans, Climate, and the Natural World, eds. C. B. Field, M. R. Raupach, pp. 257-275. Island Press, Washington.

Gruber N., Friedlingstein P., Field C. B. et al. 2004. The vulnerability of the carbon cycle in the 21 st century: an assessment of carbon-climate-human interactions. In The Global Carbon Cycle: Integrating Humans, Climate, and the Natural World, eds. C. B. Field, M. R. Raupach, pp. 45-76. Island Press, Washington.

Hein R., Crutzen P. J., Heimann M. 1997. An inverse modelling approach to investigate the global atmospheric methane cycle. Global Biogeochem.Cycles 11: 43-76.

Holland E. A., Braswell B. H., Lamarque J. F. et al. 1997. Variations in the predicted spatial distribution of atmospheric nitrogen deposition and their impact on carbon uptake by terrestrial ecosystems.

J.Geophys.Res.Atmos. 102: 15849-15866.

Houghton R. A. 1998. Historic role of forests in the global carbon cycle. In Carbon Dioxide Mitigation in Forestry and Wood Industry, eds. G. H. Kohlmaier, M. Weber, R. A. Houghton, pp. 1-24. Springer-Verlag, Berlin.

Houghton R. A. 1999. The annual net flux of carbon to the atmosphere from changes in land use 1850-1990. Tellus Ser.B 51: 298-313. 
Houghton R. A. 2003. Why are estimates of the terrestrial carbon balance so different? Global Change Biol. 9: 500509.

Houghton R. A., Hackler J. L. 2000. Changes in terrestrial carbon storage in the United States. 1: The roles of agriculture and forestry. Global Ecol.Biogeog. 9: 125-144.

Houghton R. A., Hackler J. L., Lawrence K. T. 2000. Changes in terrestrial carbon storage in the United States. 2: The role of fire and fire management. Global Ecol.Biogeog. 9: 145-170.

Houweling S., Kaminski T., Dentener F. J., Lelieveld J., Heimann M. 1999. Inverse modeling of methane sources and sinks using the adjoint of a global transport model. J.Geophys.Res. 104: 26137-26160.

IPCC 2001. Climate Change 2001: The Scientific Basis. Contribution of Working Group I to the Third Assessment Report of the Intergovernmental Panel on Climate Change, Cambridge University Press, Cambridge, United Kingdom and New York.

IPCC 2007. Climate change 2007: the physical science basis. Summary for policymakers. IPCC Secretariat, Geneva.

Jacobson M., Charleson R. J., Rodhe H., Orians G. H. 2000. Earth System Science: From Biogeochemical Cycles to Global Change. Academic Press, New York, 527 pp.

Janssens I. A., Freibauer A., Schlamadinger B. et al. 2005. The carbon budget of terrestrial ecosystems at countryscale - a European case study. Biogeosciences 2: 15-26.

Jarvis P., Linder S. 2000. Botany - Constraints to growth of boreal forests. Nature 405: 904-905.

Jones P. D., Parker D. E., Osborn T. J., and Briffa K. R. 2006. Global and hemispheric temperature anomalies - land and marine instrumental records. Trends: A Compendium of Data on Global Change, Carbon Dioxide Information Analysis Center, Oak Ridge National Laboratory, U.S. Department of Energy, Oak Ridge, Tennessee, USA.

Jorgenson T. M., Shur Y. L., Pullman E. R. 2006. Abrupt increase in permafrost degradation in Arctic Alaska. 
Geophys.Res.Lett. 33: doi:10. 1029/2005GL024960.

Keeling C. D. and Whorf T. P. 2005. Atmospheric CO2 records from sites in the SIO air sampling network. Trends: A Compendium of Data on Global Change, Carbon Dioxide Information Analysis Center, Oak Ridge National Laboratory, U.S. Department of Energy, Oak Ridge, Tennessee, USA.

Knorr W., Prentice I. C., House J. I., Holland E. A. 2005. Long-term sensitivity of soil carbon turnover to warming. Nature 433: 298-301.

Kurz W. A., Apps M. J. 1999. A 70-year retrospective analysis of carbon fluxes in the Canadian forest sector. Ecol.Applications 9: 526-547.

Langenfelds R. L., Francey R. J., Pak B. C., Steele L. P., Lloyd J., Trudinger C. M., Allison C. E. 2002. Interannual growth rate variations of atmospheric CO2 and its delta C-13, H-2, CH4, and CO between 1992 and 1999 linked to biomass burning. Global Biogeochem.Cycles 16.

Le Quere C., Metzl N. 2004. Natural processes regulating the ocean uptake of CO2. In The Global Carbon Cycle: Integrating Humans, Climate, and the Natural World, eds. C. B. Field, M. R. Raupach, pp. 243-255. Island Press, Washington.

Lelieveld J., Crutzen P. J., Dentener F. J. 1998. Changing concentration, lifetime and climate forcing of atmospheric methane. Tellus Ser.B 50: 128-150.

Lloyd J., Taylor J. A. 1994. On the temperature dependence of soil respiration. Functional Ecology 8: 315-323.

Luger A. D., Moll E. J. 1993. Fire protection and afromontane forest expansion in Cape Fynbos. Biological Conservation 64: 51-56.

Luo Y., Su B., Currie W. S. et al. 2004. Progressive nitrogen limitation of ecosystem responses to rising atmospheric carbon dioxide. BioScience 54: 731-739.

Luo Y. Q., Wan S. Q., Hui D. F., Wallace L. L. 2001. Acclimatization of soil respiration to warming in a tall grass 
prairie. Nature 413: 622-625.

Mack F., Hoffstadt J., Esser G., Goldammer J. G. 1996. Modeling the influence of vegetation fires on the global carbon cycle. In Biomass burning and global change, ed. J. S. Levine, MIT Press, Cambridge, MA.

Marland G., Boden T. A., and Andres R. J. 2006. Global, regional, and national CO2 emissions. Trends: A Compendium of Data on Global Change, Carbon Dioxide Information Analysis Center, Oak Ridge National Laboratory, U.S. Department of Energy, Oak Ridge, Tennessee, USA.

Mikaloff Fletcher S. E., Tans P. P., Bruhwiler L. M., Miller J. B., Heimann M. 2004a. CH4 sources estimated from atmospheric observations of $\mathrm{CH} 4$ and its $13 \mathrm{C} / 12 \mathrm{C}$ isotopic ratios: 1 . Inverse modelling of source processes. Global Biogeochem.Cycles 18: doi:10.1029/2004GB002223.

Mikaloff Fletcher S. E., Tans P. P., Bruhwiler L. M., Miller J. B., Heimann M. 2004b. CH4 sources estimated from atmospheric observations of $\mathrm{CH} 4$ and its $13 \mathrm{C} / 12 \mathrm{C}$ isotopic ratios: 2 . Inverse modelling of $\mathrm{CH} 4$ fluxes from geographical regions. Global Biogeochem.Cycles 18: doi:10.1029/2004GB002224.

Mosier A. R., Duxbury J. M., Freney J. R., Heinemeyer O., Minami K., Johnson D. E. 1998. Mitigating agricultural emissions of methane. Climatic Change 40: 39-80.

Mouillot F., Field C. B. 2005. Fire history and the global carbon budget: a 1 degrees x 1 degrees fire history reconstruction for the 20th century. Global Change Biol. 11: 398-420.

Nadelhoffer K. J., Emmett B. A., Gundersen P. et al. 1999. Nitrogen deposition makes a minor contribution to carbon sequestration in temperate forests. Nature 398: 145-148.

Nakicenovic N., Alcamo J., Davis G. et al. 2000. IPCC Special Report on Emissions Scenarios. Cambridge University Press, Cambridge, U.K. and New York.

Nemani R. R., Keeling C. D., Hashimoto H. et al. 2003. Climate-driven increases in global terrestrial net primary production from 1982 to 1999 . Science 300: 1560-1563. 
Norby R. J., DeLucia E. H., Gielen B. et al. 2005. Forest response to elevated CO2 is conserved across a broad range of productivity. Proc.Natl.Acad.Sci.U.S.A. 102: 18052-18056.

Nowak R. S., Ellsworth D. S., Smith S. D. 2004. Functional responses of plants to elevated atmospheric CO2 - do photosynthetic and productivity data from FACE experiments support early predictions? New Phytologist 162: $253-280$.

Olivier J. G. J., Bouwman A. F., Berdowski J. J. M. et al. 1999. Sectoral emission inventories of greenhouse gases for 1990 on a per country basis as well as on 1x1. Environmental Science and Policy 2: 241-263.

Oren R., Ellsworth D. S., Johnsen K. H. et al. 2001. Soil fertility limits carbon sequestration by forest ecosystems in a CO2-enriched atmosphere. Nature 411: 469-472.

Owensby C. E., Ham J. M., Knapp A. K., Bremer D., Auen L. M. 1997. Water vapour fluxes and their impact under elevated CO2 in a C4-tallgrass prairie. Global Change Biol. 3: 189-195.

Pacala S. W., Hurtt G. C., Baker D. et al. 2001. Consistent land- and atmosphere-based US carbon sink estimates. Science 292: 2316-2320.

Page S. E., Siegert F., Rieley J. O., Boehm H. D. V., Jaya A., Limin S. 2002. The amount of carbon released from peat and forest fires in Indonesia during 1997. Nature 420: 61-65.

Page S. E., Wust R. A. J., Weiss D., Rieley J. O., Shotyk W., Limin S. H. 2004. A record of Late Pleistocene and Holocene carbon accumulation and climate change from an equatorial peat bog (Kalimantan, Indonesia): implications for past, present and future carbon dynamics. Journal of Quaternary Science 19: 625-635.

Pataki D. E., Huxman T. E., Jordan D. N. et al. 2000. Water use of two Mojave Desert shrubs under elevated CO2. Global Change Biol. 6: 889-897.

Raupach M. R., Marland G., Ciais P., Le Quere C., Canadell J. G., Klepper G., Field C. B. 2007. Global and regional drivers of accelerating CO2 emissions. Proc.Natl.Acad.Sci.U.S.A. submitted. 
Raupach M. R., Rayner P. J., Barrett D. J. et al. 2005. Model-data synthesis in terrestrial carbon observation: methods, data requirements and data uncertainty specifications. Global Change Biol. 11: 10.1111/j.13652486.2005.00917.x.

Sabine C. L., Heimann M., Artaxo P. et al. 2004. Current status and past trends of the global carbon cycle. In The Global Carbon Cycle: Integrating Humans, Climate, and the Natural World, eds. C. B. Field, M. R. Raupach, pp. 17-44. Island Press, Washington.

Schellnhuber H. J., Cramer W., Nakicenovic N., Wigley T. M. L., Yohe G. 2006. Avoiding dangerous climate change. Cambridge University Press, Cambridge, 392 pp.

Smith L. C., Sheng Y., MacDonald G. M., Hinzman L. D. 2005. Disappearing Arctic lakes. Science 308: 1429.

Steffen W. L., Sanderson A., Tyson P. D. et al. 2004. Global Change and the Earth System: a Planet Under Pressure. Springer, Berlin, 336 pp.

Tarnocai C. 1999. The effect of climate warming on the carbon balance of cryosols in Canada. Permafrost and Periglacial Processes 10: 251-263.

Townsend A. R., Braswell B. H., Holland E. A., Penner J. E. 1996. Spatial and temporal patterns in terrestrial carbon storage due to deposition of fossil fuel nitrogen. Ecol.Applications 6: 806-814.

Valentini R., Matteucci G., Dolman A. J. et al. 2000. Respiration as the main determinant of carbon balance in European forests. Nature 404: 861-865.

van der Werf G. R., Randerson J. T., Collatz G. J., Giglio L. 2003. Carbon emissions from fires in tropical and subtropical ecosystems. Global Change Biol. 9: 547-562.

van der Werf G. R., Randerson J. T., Collatz G. J. et al. 2004. Continental-scale partitioning of fire emissions during the 1997 to $2001 \mathrm{El}$ Nino/La Nina period. Science 303: 73-76.

van der Werf G. R., Randerson J. T., Giglio L., Collatz G. J., Kasibhatla P. S., Arellano A. F. 2006. Interannual 
variability in global biomass burning emissions from 1997 to 2004. Atmospheric Chemistry and Physics 6: 34233441.

Wang J. S., Logan J. A., McElroy M. B., Duncan B. N., Megretskaia I. A., Yantosca R. M. 2004. A 3-D model analysis of the slowdown and interannual variability in the methane growth rate from 1988 to 1997. Global Biogeochem.Cycles 18: GB3011, doi:10.1029/2003GB002180.

Wuebbles D. J., Hayhoe K. 2002. Atmospheric methane and global change. Earth-Science Reviews 57: 177-210.

Zimov S. A., Schuur E. A. G., Chapin F. S. 2006. Permafrost and the global carbon budget. Science 312: 1612-1613. 